Boise State University

ScholarWorks

$2-2020$

Saving the Vicuña: The Political, Biophysical, and Cultural History of Wild Animal Conservation in Peru, 1964-2000

\author{
Emily Wakild \\ Boise State University
}

This is a pre-copyedited, author-produced PDF of an article accepted for publication in The American Historical Review following peer review. The version of record

Wakild, E. (2020). Saving the Vicuña: The Political, Biophysical, and Cultural History of Wild Animal Conservation in Peru, 1964-2000. The American Historical Review, 125(1), 54-88.

is available online at https://doi.org/10.1093/ahr/rhz939. The content of this document may vary from the final published version. 
This is an author-produced, peer-reviewed version of this article. The final, definitive version of this document can be found online at The American Historical Review, published by Oxford University Press. Copyright restrictions may apply. doi: 10.1093/ahr/rhz939

\title{
Saving the Vicuña: The Political, Biophysical, and Cultural History of Wild Animal Conservation in Peru, 1964-2000
}

\author{
Emily Wakild \\ Boise State University
}

Conservation campaigns in the late twentieth century - to save the turtles, save the whales, save the pandasexemplify episodic but widespread efforts across world cultures to protect wild creatures. ${ }^{1}$ Easily identifiable and charismatic animals served to rally social interest in larger ecological goals, including conserving habitats, maintaining ecosystems, and changing behaviors. Concern over the fate of wild animals rose as human populations simultaneously threatened them in pervasive new ways. Why did campaigns to save individual species largely prove successful at preventing the extinction of those animals, and what do these efforts tell us about broader political, economic, and environmental history? Despite popular recognition of extinct and nearly extinct North American animals, such as the passenger pigeon and the buffalo, historians have a limited understanding of how efforts by individuals, communities, national governments, and international organizations to "save" wildlife contributed to species survival in other world regions. Some historians have argued that conservation was a privilege of wealthy, democratic countries and international organizations. ${ }^{2}$ On the contrary, conservation efforts in poor, underdeveloped, and unstable countries have reversed the fate of certain species by producing new ways for varied social groups to relate to wild animals.

Take the vicuña, for example. A smaller wild cousin to the llama, vicuña (Vicugna vicugna) are about the size of a collie, with long, slender necks, oversized dark eyes, and upturned, mouths which appear to be smiling. ${ }^{3}$ They inhabit the high southern Andes, with the largest concentrations in Peru. Vicuña grow soft, exquisitely warm wool that once fetched prices three to five times the cost of cashmere, an attribute that decimated the species in the mid-twentieth century. Because vicuña have notoriously vicious temperaments and have never been effectively bred in captivity, wool-harvesting involved killing wild animals rather than shearing or domesticating them. ${ }^{4}$ As a result, the vicuña nearly went the way of the dodo.<FIG. 1 NEAR HERE>

The modern saga of saving the vicuña spanned five decades with complex contours, but the basic narrative goes something like this: Demand for their wool as a luxury product increased until vicuña populations dropped from an estimated 1 million animals across their entire range in 1940 to a nadir of 6,000 by $1965 .{ }^{5}$ Peruvian government officials then took steps to stop the poaching. ${ }^{6}$ They signed international treaties restricting trade, set up a territorial

\footnotetext{
${ }^{1}$ Irene Kinan and Paul Dalzell, "Sea Turtles as a Flagship Species: Different Perspectives Create Conflicts in the Pacific Islands," Maritime Studies 3, no. 2 (2005): 195-212; Frederick Rowe Davis, The Man Who Saved Sea Turtles: Archie Carr and the Origins of Conservation Biology (New York, 2007); George B. Schaller, The Last Panda (Chicago, 1994); David Day, The Whale War (San Francisco, 1987); Frank Zelko, Make It a Green Peace! The Rise of Countercultural Environmentalism (New York, 2013).

${ }^{2}$ Donald Worster, "Nature, Liberty, and Equality," in Michael Lewis, ed., American Wilderness: A New History (New York, 2007), $263-272$. Ramachandra Guha and Joan Martinez-Alier have critiqued Western environmentalism as either wilderness-oriented or utilitarian and argued that an "environmentalism of the poor" directly confronts Western growth mentalities. Neither argument makes room for proactive species conservation efforts within poor countries. Guha, "Radical American Environmentalism and Wilderness Preservation: A Third World Critique," Environmental Ethics 11, no. 1 (1989): 71-83; Martinez-Alier, The Environmentalism of the Poor: A Study of Ecological Conflicts and Valuation (Cheltenham, 2002).

${ }^{3}$ There are four camelids in South America: llama (lama glama), guanaco (lama ganicoe), alpaca (vicugna pacos), and vicuña.

${ }^{4}$ Wilfredo Pérez Ruiz, La saga de la vicuña (Lima, 1994), 49; Gabriela Lichtenstein, "Vicuña Conservation and Poverty Alleviation? Andean Communities and International Fibre Markets," International Journal of the Commons 4, no. 1 (2010): 100-121; David Coggins, "Why Does a Vicuña Jacket Cost \$21,000?," Wall Street Journal, September 20, 2013.

${ }^{5}$ Exact population figures are a subject of debate; there is little dispute about the general trajectory of decline and recovery. For estimates, see Antonio Brack Egg, "La situación actual de la población de vicuñas en Pampa Galeras y zonas aledañas y recomendaciones para su manejo," Proyecto Especial de Utilización Racional de la Vicuña, Ministerio de Agricultura y Alimentación, January 1980, located in the Centro de Datos de Conservación, Universidad Nacional Agraria La Molina, Lima, Peru [hereafter CDC-UNALM]; K. C. Otte and R. K. Hofmann, "The Debate about the Vicuna Population in Pampa Galeras Reserve," in Peter A. Jewell and Sidney Holt, eds., Problems in Management of Locally Abundant Wild Mammals (New York, 1981), 259-275; S. K. Eltringham and W. J. Jordan, "The Vicuna of the Pampa Galeras National Reserve: The Conservation Issue," ibid., 277-290; Matt Moffett, "Despues de Sendero . . . a proteger vicuñas," El Tiempo, June 13, 1997; Lichtenstein, "Vicuña Conservation and Poverty Alleviation?," 110. In 1972, fewer than 100 vicuña were believed to live in Argentina, and between 450 and 650 were counted in Chile; Jeffrey Boswall, "Comentarios sobre el estado de la vicuña en la Argentina," memorandum prepared for the Comisión de Servicio de Reservas, IUCN, Morges 1110, Switzerland, April 1972, CDC-UNALM.

${ }^{6}$ Poaching refers to the illegal or illegitimate harvesting of animals. As used here, poaching implies the violation of state restrictions on communal or public resources for private gain, an accusation made in this case by villagers, scientists, and bureaucrats alike. While some authors, including Louis S. Warren, The Hunter's Game: Poachers and Conservationists in Twentieth-Century America (New Haven, Conn., 1997), 4, argue that by
} 
This is an author-produced, peer-reviewed version of this article. The final, definitive version of this document can be found online at The American Historical Review, published by Oxford University Press. Copyright restrictions may apply. doi: 10.1093/ahr/rhz939

reserve at the site of the largest remaining population (Pampa Galeras in Ayacucho Province), and enacted community development plans that would permit resident peoples to harvest and sell vicuña wool once the population recovered. Results rapidly exceeded expectations, and within a decade, the pressures of animal abundance threatened the reserve's ecological viability. Fierce debates erupted within and beyond Peru over what should happen next. Should the animals be selectively culled because of the looming drought and deteriorating grassland, with the meat and wool commercialized to benefit local populations? Or should strict conservation measures remain in force because the vicuña was an "inviolable national symbol"? ${ }^{7}$ The debate collapsed in 1980 with the outbreak of political violence, a guerrilla war launched by a Maoist rebel movement known as the Shining Path, which included attacks on the vicuña reserve. ${ }^{8}$ Poachers returned to illegally harvest the animals, which resolved the overpopulation debate but caused vicuña numbers to again plummet. When political stability returned in the 1990s, the national government revived conservation measures, especially the reserve and restrictions. More than 350,000 wild vicuña live in Peru today.

Politics pervaded the landscapes of vicuña survival. ${ }^{9}$ Peru's national political scene was particularly volatile during the decades of vicuña conservation. The government vacillated from the presidency of Fernando Belaúnde Terry, who was democratically elected in 1963 (when state vicuña conservation efforts began), to a leftist military regime initiated with a coup in 1968 (when the reserve was created), and back to the same Belaúnde, who was reelected president in 1980 (when vicuña populations outpaced reserve capacity and discussions of culling animals peaked). The democratic transition was marred by the armed conflict triggered by the Shining Path, which killed at least 69,000 people (and resulted in the reserve's closure and the resumption of poaching). National politics entered a neoliberal stage under elected president Alberto Fujimori, whose rule devolved into authoritarianism in 1992 when he closed the congress and suspended the constitution (during which time the reserve was reopened and expanded). ${ }^{10}$ In each of these periods - except for the height of the conflict with the Shining Path - a national commitment to vicuña conservation remained in place. Different political regimes appropriated the vicuña and continued to structure its protection through state agencies and institutions. It seems that this wild animal, which is still prominently featured on the Peruvian national shield, provided a touchstone of unity, and that public sentiment for conservation was consistently popular through divisive political transitions. ${ }^{1}{ }^{1}$ FIG. 2 NEAR HERE>

And yet, what the vicuña symbolized proved to be highly contested. Peruvians and foreigners who lived far from the animal's highland habitat repeatedly portrayed the vicuña as a sort of mascot for rural indigenous and mestizo peasants, or campesinos. In a resurrected form of the noble savage, journalists, bureaucrats, and urbanites romanticized vicuña survival in ways that essentialized rural people on the same landscape. To select but one example, the May 1981 cover of the magazine International Wildlife shows a pensive campesino grasping a makeshift leash around the outstretched neck of a vicuña. The tether winds beneath the man and around the animal's neck. The vicuña does not resist but instead leans in to nearly touch the campesino nose to nose. Photographs such as this promoted the idea that saving the vicuña meant saving the highlanders who relied on the animal for their livelihoods. But this intimacy had never existed; in fact, vicuña represented high social status and were historically off-limits and even undesirable to campesinos. ${ }^{12}$ Enterprising poachers — rarely drawn from resident communities - harvested vicuña to serve unreliable

naming customary wildlife hunting "poaching," state agents acted to dispossess poor and native groups. Here poaching generally refers to those who violate norms enforced by the state to protect a collective resource.

7 "Con complicidad burocrática se extinguen peces y vicuñas," Oiga 78 (Lima), June 4, 1979.

${ }^{8}$ For an introduction to the Peruvian Communist Party-Shining Path, see Steve J. Stern, ed., Shining and Other Paths: War and Society in Peru, 1980-1995 (Durham, N.C., 1998); Deborah Poole and Gerardo Rénique, Peru: Time of Fear (New York, 1992); Gustavo Gorriti, The Shining Path: A History of the Millenarian War in Peru (Chapel Hill, N.C., 1999); and the collection of writings by Carlos Iván Degregori, How Difficult It Is to Be God: Shining Path's Politics of War in Peru, 1980-1999, ed. Steve J. Stern, trans. Nancy Appelbaum (Madison, Wis., 2012). For excellent recent histories, see Miguel La Serna, The Corner of the Living: Ayacucho on the Eve of the Shining Path Insurgency (Chapel Hill, N.C., 2012); and Jaymie Patricia Heilman, Before the Shining Path: Politics in Rural Ayacucho, 1895-1980 (Stanford, Calif., 2010).

${ }^{9}$ A rich literature on politicized landscapes exists for Latin America. See Christopher R. Boyer, Political Landscapes: Forests, Conservation, and Community in Mexico (Durham, N.C., 2015); Claudia Leal, Landscapes of Freedom: Building a Postemancipation Society in the Rainforests of Western Colombia (Tucson, Ariz., 2018); Perla Zusman, "La geografia histórica, la imaginación y los imaginarios geográficos," Revista de Geografía Norte Grande, no. 54 (May 2013): 51-66; Cynthia Radding, Landscapes of Power and Identity: Comparative Histories in the Sonoran Desert and the Forests of Amazonia from Colony to Republic (Durham, N.C., 2006); Jens Andermann, Tierras en trance: Arte y naturaleza después del paisaje (Santiago, Chile, 2018).

${ }^{10}$ Fujimori was overwhelmingly reelected in 1995, but he was impeached in 2000 and is currently serving out a prison sentence for human rights violations. From 2001 to 2003, Peru's Comisión de la Verdad y Reconciliación investigated the violent internal conflict and then published a ninevolume, nearly 8,000-page report, Comisión de la Verdad y Reconciliación, Informe Final, (Lima, CVR 2003). Available at http://www.cverdad.org.pe/.

${ }^{11}$ This shield is often displayed on the flags flown in front of government buildings. Salomón Vilches Murga, La vicuña es riqueza nacional, pamphlet published by the Ministerio de Agricultura, Servicio Forestal y de Caza (Lima, 1967).

${ }^{12}$ Luis J. Cueto, Carlos F. Ponce, Eric Cardich, and Manuel A. Ríos, El manejo de la vicuña para el desarrollo rural en los Altos Andes del Perú, report, 1983, CDC-UNALM. 
This is an author-produced, peer-reviewed version of this article. The final, definitive version of this document can be found online at The American Historical Review, published by Oxford University Press. Copyright restrictions may apply. doi: 10.1093/ahr/rhz939

luxury wool markets; campesinos raised sheep and llamas that fetched predictable local prices. The invented link between campesinos and vicuña had neither historical nor cultural roots; it reproduced a form of geographical exclusion that persisted on the economic periphery. ${ }^{13}$ Such popular stereotypes - that saving the vicuña was a nod toward ethnic inclusion or the preservation of campesino traditions-disguised the fictive and incomplete incorporation of Andean highlanders into Peruvian society (a major cause of the Shining Path conflict) and overlooked the long history of resource division in a nation starkly fragmented by race and geography. ${ }^{14}$ The imagined camaraderie between campesinos and vicuña on display in international conservation circles by the 1980s lacked the temporal roots of conservation activity in the mid-1960s and dramatically misrepresented conservation's key participants. ${ }^{15}$

Excavating the space between the cultural imaginaries of animals and the observed lives of those same animals, reveals a nexus of environmental history. ${ }^{16}$ Historians can use physiological features, family groups, dung heaps, and other facets of vicuña biology to understand the ways in which vicuña have inhabited and changed the landscapes conserved in their name. For example, their soft hooves cause little damage to fragile soils, which makes it possible for more vicuña to survive in smaller ranges than those needed by domesticated animals such as sheep. Other attributes, including the early onset of reproduction, facilitated generational population increases that marked conservation success, or "overpopulation," on a surprisingly rapid timescale. The unexpected increase in the number of vicuña testified to the changing trajectories of their lives and presented dilemmas about whether to translocate or remove them. Experts, namely field biologists, made recommendations about reserve management by relying on their own observations within the reserve and bureaucrats used these recommendations to make policy decisions. Yet biologists' inability to fully know the animals or forecast especially their reproductive behavior left room for scientific recommendations to be challenged. The vicuña's biological particularities allowed the animals' survival to be secured sooner than the society around them had predicted. Because of this unpredictability, popular and elite claims about the intrinsic value of vicuña repeatedly thwarted scientists' expertise, mutually affecting these social groups and the wild animals. The tensions between the lives of vicuña and humans' understanding of them can help to expand historical ideas about the multinatural — not merely multinational—relationships that exist in particular landscapes. ${ }^{17}$

Within this shifting political, cultural, and biophysical context, members of distinct social groups worked to save the vicuña, but they hardly agreed upon why doing so mattered. Government officials, largely based in the national capital of Lima, imagined a symmetry between the livelihoods of rural people and the survival of the vicuña and therefore advocated conserving the landscapes where both remained. Scientists, taking a more utilitarian approach, similarly envisioned protecting wild animals as a means toward social development and thus advocated trade restrictions and reserve formation. Many elites and campesinos alike argued that the market value of the wool justified the animal's protection. Yet in practical terms, vicuña wool was a luxury item with a market that was difficult to reach, one that was functionally and legally unavailable to campesinos. Vicuña conservation seems to have provided one of the first platforms for what would come to be called "sustainable development" or "community-based conservation" by giving resident communities exclusive access to the economic proceeds from wild animals. ${ }^{18}$ For many highland residents,

\footnotetext{
${ }^{13}$ Nils Jacobsen, Mirages of Transition: The Peruvian Altiplano, 1780-1930 (Berkeley, Calif., 1993), 165. Jacobsen mentions the sale of alpaca and vicuña wool in the late nineteenth century and shows that even Lima elites were unable to capture the revenues domestically, as nearly all profits went to London.

${ }^{14}$ Florencia E. Mallon, The Defense of Community in Peru's Central Highlands: Peasant Struggle and Capitalist Transition, $1860-1940$ (Princeton, N.J., 1983); Enrique Mayer, Ugly Stories of the Peruvian Agrarian Reform (Durham, N.C., 2009); Heilman, Before the Shining Path; La Serna, The Corner of the Living.

${ }^{15}$ Raf De Bont, “Primitives' and Protected Areas: International Conservation and the 'Naturalization' of Indigenous People, ca. 1910-1975," Journal of the History of Ideas 76, no. 2 (2015): 215-236.

${ }^{16}$ There is an exciting literature on animals in history. For an introduction, see Nancy J. Jacobs, "The Great Bophuthatswana Donkey Massacre: Discourse on the Ass and the Politics of Class and Grass," American Historical Review 106, no. 2 (April 2001): 485-507; Harriet Ritvo, "Animal Planet," Environmental History 9, no. 2 (2004): 204-220; Ritvo, Noble Cows and Hybrid Zebras: Essays on Animals and History (Charlottesville, Va., 2010); Sandra Swart, “'But Where's the Bloody Horse?' Textuality and Corporeality in the 'Animal Turn,” Journal of Literary Studies 23, no. 3 (2007): 271-292; Marcy Norton, "Going to the Birds: Animals as Things and Beings in Early Modernity," in Paula Findlen, ed., Early Modern Things: Objects and Their Histories, 1500-1800 (New York, 2013), 53-83; Alan Mikhail, The Animal in Ottoman Egypt (Oxford, 2013). For Latin America, see Lauren Derby, "Bringing the Animals Back in: Writing Quadrupeds into the Environmental History of Latin America and the Caribbean," History Compass 9, no. 8 (2011): 602-621; Pablo Camus, Sergio Castro, and Fabían Jaksic, "El conejo Europeo en Chile: Historia de una invasión biológica," Historia 41, no. 2 (2008): 305-339; Martha Few and Zeb Tortorici, eds., Centering Animals in Latin American History (Durham, N.C., 2013)

${ }^{17}$ Eduardo Viveiros de Castro, "Perspectivismo e multinaturalismo na América indígena," in Viveiros de Castro, A inconstância da alma selvagem e outros ensaios de antropologia (São Paulo, 2002), 345-399; Ricardo Cavalcanti-Schiel, "Las muchas naturalezas en los Andes," Perifèria: Revista de Recerca i Formación en Antropologia 7 (2007), https://doi.org/10.5565/rev/periferia.179; Jaime Lorimer, Wildlife in the Anthropocene: Conservation after Nature (Minneapolis, 2015).

${ }^{18}$ Edgar Sánchez Infantas and Moises Yaringano R., "Manejo de vicuñas: Primera aproximación al desarrollo de un modelo de manejo,” (Ministerio de Agricultura, Proyecto Especial Utilización Racional de la Vicuña, Lima, 1987), CDC-UNALM.
} 
This is an author-produced, peer-reviewed version of this article. The final, definitive version of this document can be found online at The American Historical Review, published by Oxford University Press. Copyright restrictions may apply. doi: 10.1093/ahr/rhz939

vicuña were a means to another end: jobs in conservation. Dozens of local residents, whether employed as guards in the reserve or collecting data for scientists, did the hard work of conservation on the ground. ${ }^{19}$ Their collective engagement with the project reveals that at least some residents sustained the idea of conservation in a specific locale. Support for vicuña protection extended far beyond the animals' immediate utility. Ethical claims about the vicuña's symbolic importance came mainly from elite powerbrokers in reaction to the success of the reserve and the subsequent scientific consensus that excess animals should be culled. ${ }^{20}$ While no single view-from utilitarian significance to intrinsic worth - consistently dominated the conservation effort, the symbolic national status of the vicuña came to overshadow its proposed management for rural people. That is to say, Peruvians largely implemented and supported the measures necessary to save a single species from extinction because of its inherent value, not simply its practical utility. In all of these ways, conservation reoriented relationships among people and wild animals.

But why would a politically volatile, economically marginalized, and socially divided nation invest significant material resources in the conservation of wild animals? Short- and long-term processes contributed to a rising consciousness about human impacts on nonhuman nature, which helped foster a consensus about the value of the vicuña, a phenomenon that has likely been replicated in other societies. The political moment of the late 1960s highlights a wave of radical social thought manifested in various movements. The vicuña's survival should be seen against the backdrop of student protests, revolutionary regimes, decolonization projects, and environmental awareness. ${ }^{21}$ Substantial efforts to save the vicuña emerged in tandem with similar desires to remake an unequal world. Conservation efforts enjoyed a burst of momentum when international environmental institutions sought ways to expand their profile, exemplified in part by the Latin American Conference on the Conservation of Renewable Natural Resources held in San Carlos de Bariloche in 1968. ${ }^{22}$ This conference contributed to the idea that nations should act to change the course of environmental degradation. Increasing scientific debates about extinction and species interaction formed part of the broader context of understanding human impacts on both. These ideas took legal form in the early 1970s through international treaties prohibiting trade in threatened and endangered species, and a series of policies that allowed states to intervene. ${ }^{23}$ Personal experiences of loss by peasants, bureaucrats, scientists, and elites alike, including seeing the decline of the vicuña in the span of a single decade, helped strengthen support for conservation programs. ${ }^{24}$ And certainly, the deep human sympathy that both authentic and invented exposure to wildlife evokes has caused millions of people to lament the prospect of a world with silent springs and diminished animal populations. These emotions have never been limited to developed or democratic countries. ${ }^{25}$

\footnotetext{
${ }^{19}$ Rudolf Hofmann and Kai-Christian Otte, Utilización de la vicuña en el Perú (Eschborn, 1977), Frankfurt Zoological Society Archive, Frankfurt, Germany [hereafter FZS], Vicuña file, Projekte ZGF-Nr. 831/78.

${ }^{20}$ Edmundo Rey Riveros, "Flora, fauna y conservación," La Prensa (Lima), December 6, 1978; Felipe Benavides Barreda, "Una voz clamando en el desierto," La Prensa, July 4, 1978.

${ }^{21}$ Substantial literature expands this view of environmental and social movements for the U.S., including the sources in note 2 and Samuel P. Hays, Beauty, Health and Permanence: Environmental Politics in the United States, 1955-1985 (New York, 1987); Robert Gottlieb, Forcing the Spring: The Transformation of the American Environmental Movements (Washington, D.C., 1993); James Morton Turner, The Promise of Wilderness: American Environmental Politics since 1964 (Seattle, Wash., 2012); Chad Montrie, The Myth of Silent Spring: Rethinking the Origins of American Environmentalism (Berkeley, Calif., 2018). Much less has been done to contextualize environmentalism or environmentalist movements beyond the U.S.

${ }^{22}$ International Union for Conservation of Nature and Natural Resources, Proceedings of the Latin American Conference on the Conservation of Renewable Natural Resources, San Carlos de Bariloche, Argentina, 27 March-2 April 1968 (Morges, 1968).

${ }^{23}$ Simon Lyster, International Wildlife Law: An Analysis of International Treaties Concerned with the Conservation of Wildlife (1985; repr., Cambridge, 2012); Kathryn A. Kohm, ed., Balancing on the Brink of Extinction: The Endangered Species Act and Lessons for the Future (Washington, D.C., 1991); Peter Coates, "Creatures Enshrined: Wild Animals as Bearers of Heritage," Past \& Present 226, supplement 10 (2015): 272-298; Javiera Barandiarán, Science and Environment in Chile: The Politics of Expert Advice in a Neoliberal Democracy (Cambridge, Mass., 2018).

${ }^{24}$ Flavio Bázan, head of the Peruvian Forestry Service in the 1960s, traveled through Pampa Galeras and saw condors and scavengers devouring skinned vicuñas whose wool had been taken from poached animals. He initiated conservation measures based on this memory. See Marc Dourojeanni, "Reserva nacional Pampa Galeras, la primera década," CDC-UNALM.

${ }^{25}$ For a sample of similar laments, see Rafael Elizalde Mac-Clure, La sobrevivencia de Chile: La conservación de sus recursos naturales renovables (Santiago, 1958); Enrique Beltrán, "Use and Conservation: Two Conflicting Principles," in Alexander B. Adams, ed., First World Conference on National Parks (Washington, D.C., 1962), 35-43; José Liebermann, La Argentina contra el desierto (Buenos Aires, 1968).
} 
This is an author-produced, peer-reviewed version of this article. The final, definitive version of this document can be found online at The American Historical Review, published by Oxford University Press. Copyright restrictions may apply. doi: 10.1093/ahr/rhz939

The form that conservation took in this case — a territorial reserve — helps explain why Peruvians protected the vicuña. Nearly every nation engages in some form of territorial conservation. ${ }^{26}$ Territories constitute a place where states can act and provide a setting for expressing sovereignty. And yet, conservation reveals relationships more complex than merely a state acting upon its constituencies. The Peruvian state changed dramatically in political terms, and conservation provided a vehicle for legitimacy, debate, and meaningful action in the name of a nonhuman species. Distinct from other realms of interaction between states and animals - in agricultural production, food consumption, and disease prevention, for example-wild animal conservation offered a collective mechanism for expressing positive values regarding animals without reference to property rights or ownership, yet still within the parameters of state funding and legal supports.

National actions, not local or global efforts, prevented the vicuña's extinction. Peruvian scientists and bureaucrats, working with and within governmental agencies, designed and implemented vicuña conservation measures alongside a plan for community development. These actions confirm that many states could not effectively evict or exclude local residents; nor did all state actors want to do so. Despite a constantly changing political setting, bureaucrats and scientists succeeded in saving the vicuña by using their power, influence, and expertise to produce new ways of relating to wild animals through state-based conservation.

Until the 1950s, acute observers in the Andes might have glimpsed a cinnamon-colored vicuña roaming wild in the high-altitude arid plains, between 3,200 and 5,000 meters above sea level. ${ }^{27}$ With their thick wool, vicuña are uniquely suited to these frigid, treeless plains known as the puna, but they also proved extremely vulnerable to poaching because the extensive horizon provided few places for them to hide from well-armed humans. ${ }^{28}$ In the first systematic biological study of the vicuña in 1951, U.S. biologist Carl Koford estimated the population in Peru at 250,000. Less than a decade later, the first national census put the total number of animals at only 5,713, with 4,987 residing in the province of Ayacucho. ${ }^{29}$ Of these, 1,000 animals resided in a single ecosystem, the Galeras Plains (Pampa Galeras), a plateau 540 kilometers southeast of Lima and 25 kilometers from the nearest community, Lucanas. Population figures for wild animals are always estimates, yet it was clear that a consensus had emerged that vicuña were deeply imperiled.<FIG. 3 NEAR HERE>

\footnotetext{
${ }^{26}$ Early histories noted the exceptional and even democratic orientation of conservation activities, but dominant narratives of conservation history in the United States, sub-Saharan Africa, and South Asia increasingly explain conservation programs as conflicts between foreign and domestic actors or as favoring national and international interests over local interests. Roderick Nash's Wilderness and the American Mind (New Haven, Conn., 1967) is the classic articulation of U.S. conservation as exceptional, a notion on display in the Ken Burns documentary series The National Parks: America's Best Idea (PBS, 2009). For a range of global examples, see Jane Carruthers, The Kruger National Park: A Social and Political History (Pietermaritzburg, 1995); Lane Simonian, Defending the Land of the Jaguar: A History of Conservation in Mexico (Austin, Tex., 1995); Roderick P. Neumann, Imposing Wilderness: Struggles over Livelihood and Nature Preservation in Africa (Berkeley, Calif., 1998); Vasant K. Saberwal and Mahesh Rangarajan, Battles over Nature: Science and the Politics of Conservation (Delhi, 2003); Tina Loo, States of Nature: Conserving Canada's Wildlife in the Twentieth Century (Vancouver, B.C., 2007); Mark Cioc, The Game of Conservation: International Treaties to Protect the World's Migratory Animals (Athens, Ohio, 2009); Patrick Kupper, Creating Wilderness: A Transnational History of the Swiss National Park, trans. Giselle Weiss (New York, 2014); Paige West, Conservation Is Our Government Now: The Politics of Ecology in Papua New Guinea (Durham, N.C., 2006); Rob Nixon, Slow Violence and the Environmentalism of the Poor (Cambridge, Mass., 2011); Charles Geisler, "A New Kind of Trouble: Evictions in Eden," International Social Science Journal 55, no. 175 (2003): 69-78. For debates among biologists, see the exchange over "New Conservation" in Conservation Biology 28, no. 1 (2014). For global collections and syntheses of conservation history, see William M. Adams, Against Extinction: The Story of Conservation (London, 2004); Dan Brockington, Rosaleen Duffy, and Jim Igoe, Nature Unbound: Conservation, Capitalism and the Future of Protected Areas (London, 2008); Mark Dowie, Conservation Refugees: The Hundred-Year Conflict between Global Conservation and Native Peoples (Cambridge, Mass., 2009); Bernhard Gissibl, Sabine Höhler, and Patrick Kupper, Civilizing Nature: National Parks in Global Historical Perspective (New York, 2012); Stan Sevens, ed., Indigenous Peoples, National Parks, and Protected Areas: A New Paradigm Linking Conservation, Culture, and Rights (Tucson, Ariz., 2014); Adrian Howkins, Jared Orsi, and Mark Fiege, eds., National Parks beyond the Nation: Global Perspectives on "America's Best Idea" (Norman, Okla., 2016); Wilko Graf von Hardenberg, Matthew Kelly, Claudia Leal, and Emily Wakild, The Nature State: Rethinking the History of Conservation (New York, 2017).

${ }^{27}$ Carl B. Koford, "The Vicuña and the Puna," Ecological Monographs 27, no. 2 (1957): 153-219; Koford, "La vicuña y la puna," unpublished report, 1951, CDC-UNALM.

${ }^{28}$ Catherine Sahley, Jorge Torres, and Jesús Sanchez, "Neoliberalism Meets Pre-Columbian Tradition: Campesino Communities and Vicuña Management in Andean Peru," Culture \& Agriculture 26, no. 1 and 2 (2004): 60-68, here 64.

${ }^{29}$ Antonio Brack Egg, "La conservación y el manejo de la vicuña como alternativa de producción en la puna," Oxapampa, Peru, 1986, 13, CDCUNALM.
} 
This is an author-produced, peer-reviewed version of this article. The final, definitive version of this document can be found online at The American Historical Review, published by Oxford University Press. Copyright restrictions may apply. doi: 10.1093/ahr/rhz939

For vicuña to be saved, they needed to be able to live where and how they had evolved for centuries. ${ }^{30}$ Vicuña and the closely related guanaco are the dominant large herbivores and the only wild ungulates in South America's arid lands. ${ }^{31}$ The Andes as a geographical unit are remarkable in terms of animal evolution - they provide the exception to the rule that large native animals capable of being domestication did not exist on the continent after the Pleistocene era. As a result, llamas and alpacas became emblematic of a pastoral heritage, while vicuña and guanacos signified the remaining richness of wildlife. ${ }^{32}$ Camelids fit in an ecological community as grazers, but vicuña have several adaptations that distinguish them from their wild and domesticated counterparts, including their continually growing incisors and soft hooves. These features mean that they nibble rather than pull grass out by the roots, and that they step lightly, leaving fragile alpine soils intact. ${ }^{33}$ Vicuña do not require water frequently, so unlike sheep, they rarely overgraze near water sources. ${ }^{34}$ Some researchers have found that water sources serve social functions for vicuña, such that family size increases with stable water supplies. ${ }^{35}$ These distinguishing features do more than differentiate the vicuña from other species; they allow vicuña to prosper where other animals do not.

Because much of the land in the sierra sits at a high altitude, grazing and herding are the most feasible economic activities. As Javier Puente has noted, available pastures and a particular suite of animals "turned seemingly hostile high altitude landscapes into domains of economic profitability for domestic producers, haciendas, and capitalist corporations alike." ${ }^{36}$ By 1960, the Ministry of Agriculture counted nearly 1 million sheep and 200,000 alpacas and llamas in Ayacucho. ${ }^{37}$ Because they need so little water, vicuña can coexist with domesticated livestock, and the animals most often avoid each other. Llama and alpaca use the same areas, but because they are accustomed to grazing close to their owners, they require denser pastures ${ }^{38}$ Cattle do less well at the altitude where vicuña prosper. While some competition over pasturelands and territory occurred, by far the largest conflicts for vicuña came with predation. Natural predators included mountain lions, condors, and foxes; herders' dogs were also known to attack and kill young vicuña. However, nonhuman animals hardly caused their precipitous decline: poachers acquiring pelts were the culprits. The balance between competition and coexistence centered on scale, but overall, territory where vicuña could reside beyond the reach of poachers had diminished.

The vicuña inhabited another niche: at the pinnacle of Latin America's animal product trade. Goods made from vicuña wool circulated widely in mid-century celebrity circles: Greta Garbo, Groucho Marx, and Nat King Cole all wore clothing made from the fiber. Dressing in vicuña wool was subtler and yet more extravagant than wearing a mink fur coat. Fifth Avenue tailors described the wool in New York Times advertisements as "soft as buttercream to touch" or "the most expensive coating fabric ever loomed." 39 Politicians also fancied the wool. In 1958, U.S. president Dwight Eisenhower's chief of staff, Sherman Adams, resigned as the result of a scandal after accepting a vicuña coat from a textile firm under investigation by the Federal Trade Commission. Visitors to the John F. Kennedy White House found

\footnotetext{
${ }^{30}$ Arturo Flores M. and Efrain Malpartida, Estudio de los pastizales en Pampa Galeras, Ministerio de Agricultura y Alimentación, Publicación Técnica No. 1, Proyecto Especial Utilización Racional de la Vicuña, n.d., CDC-UNALM; William L. Franklin, "The Social Behavior of the Vicuña," in V. Geist and F. Walther, eds., The Behaviour of Ungulates and Its Relation to Management: The Papers of an International Symposium Held at the University of Calgary, Alberta, Canada, 2-5 November 1971, 2 vols. (Morges, 1974), 2: 477-487; Rudolf K. Hofmann and KaiChristian Otte, "El censo de la vicuña silvestre," Ministerio de Agricultura del Perú.-Dirección General Forestal y de Fauna Silvestre. Publicación Técnica No. 1. Reserva Nacional de Pampa Galeras, Ayacucho, Peru 1977.

${ }^{31}$ William L. Franklin, "Contrasting Socioecologies of South America's Wild Camelids: The Vicuña and the Guanaco," in John F. Eisenberg and Devra G. Kleiman, eds., Advances in the Study of Mammalian Behavior (Shippensburg, Pa., 1983), 573-629, here 573.

${ }_{32}$ Javier Puente, "Livestock, Livelihood, and Agrarian Change in Andean Peru," in Oxford Research Encyclopedia of Latin American History, online, February 2018.

${ }^{33}$ Elinor G. K. Melville, A Plague of Sheep: Environmental Consequences of the Conquest of Mexico (London, 1997), 4.

${ }^{34}$ Carl B. Koford, "La ecología y el manejo de la vicuña en la zona de la puna del Peru" translation of article presented at the Symposium on Ecology and Management of Wild Grazing Animals in Temperate Zones, 8th Technical Meeting, International Union for Conservation of Nat ure and Natural Resources, Horces, Switzerland 1960; Hofmann and Otte, Utilización de la Vicuña en el Perú; José Luis Venero Gonzalez, "Estercoleros y revolcaderos de vicuñas," Presentation at IV Congreso Nacional de Biología, Chiclayo, Peru, 1979, CDC-UNALM.

${ }^{35}$ Jennifer E. Davies, "Population Ecology of the Vicuña at the Salinas Aguada Blanca National Reserve, Arequipa-Peru: Baseline Data for Sustainable Management" (master's thesis, University of Florida, 2003).

${ }^{36}$ Puente, "Livestock, Livelihood, and Agrarian Change in Andean Peru."

${ }^{37}$ Ministerio de Agricultura, Perú, "Primer Compendio Estadístico Agrario," vol. 2, 1991.

${ }^{38}$ Wolf Herre, "El problema de la vicuña: Análisis de la situación actual y proposiciones para su manejo futuro," Conferencia Internacional Sobre la Conservación y Manejo Racional de la Vicuña, 1971, 6, CDC-UNA-LA.

${ }^{39}$ Tailored Woman, New York Times, October 21, 1956, p99; and April 19, 1959, p3; Saks-34th, New York Times, December 16, 1953 , p19.
} 
This is an author-produced, peer-reviewed version of this article. The final, definitive version of this document can be found online at The American Historical Review, published by Oxford University Press. Copyright restrictions may apply. doi: 10.1093/ahr/rhz939

vicuña blankets draped over sofas. ${ }^{40}$ The average price of Peruvian vicuña wool in 1969 was $\$ 18$ to $\$ 20$ per pound but could reach as high as $\$ 42$, and first-quality vicuña cloth sold for $\$ 150$ a meter in London. ${ }^{41}$ The wool's luxury appeal nearly caused the vicuña's extinction.

Vicuña were hardly the only animals in modern Latin America to face annihilation. In the 1920s, birds and their feathers festooned ladies' hats and parlor rooms were filled with parrots, raising continent-wide concerns about their survival. ${ }^{42}$ In 1968, Argentina's Maria Buchinger, the first director of the Latin America desk for the Nature Conservancy, noted that for every parrot that made it into the United States alive, at least fifty perished while being transported. ${ }^{43}$ Commerce extended beyond avian species as monkeys entered medical research facilities by the thousands, reptile skins lined handbags, and turtles faced exploitation for their meat and eggs. ${ }^{44}$ The chinchilla, another animal with a valuable pelt, was functionally extinct in Peru by the $1960 \mathrm{~s} .{ }^{45}$ In the Peruvian Amazon, the value of trade in wildlife far exceeded the value of lumber. ${ }^{46}$ The lack of incentives for moderation resulted in massive destruction due to the distance and logistics of trade. Zoo traders and private collectors contributed to the commerce in wild animals, causing abundant populations to collapse. ${ }^{47}$

Several state interventions in the 1960s changed the vicuna's trajectory from extinction to recovery and set in motion new relationships with wild animals. These conservation measures were put in place in the atmosphere of developmentalism. When President Belaúnde took office in 1963 with the centrist Popular Action party, he embarked on a series of projects that promised economic development. Belaúnde prioritized plans to connect the country, such as roadbuilding and industrialization, but large peasant mobilizations in the highlands, including the occupation of thousands of hectares of hacienda lands, forced him to give land tenure some attention. By mid-1964 he had enacted an agrarian reform law that applied to private lands, although its early effects were minimal. ${ }^{48} \mathrm{He}$ also oversaw the first stages of the vicuña's protection. A second cousin of the president, Felipe Benavides, became one of the chief protagonists of vicuña conservation. Benavides initially advocated rounding up vicuña and saving them in private zoos, but forestry professors at the National Agrarian University La Molina, especially the Peruvian scientist Marc Dourojeanni and the Belgian expert Paul Pierret, suggested a public on-site reserve instead. ${ }^{49}$ By 1968 , Belaúnde faced a fractious parliament and a scandal involving oil nationalization that, combined with mounting public unrest, resulted in a coup. Nevertheless, the rising voices of concerned conservationists within elite and bureaucratic circles established formal state support for initiating the vicuña project. This support remained remarkably resilient through subsequent political shifts.

\footnotetext{
${ }^{40}$ Meg Lukens Noonan, The Coat Route: Craft, Luxury, and Obsession on the Trail of a \$50,000 Coat (New York 2013), 47-49.

${ }^{41}$ William L. Franklin, "The Last of the Vicuña," Peruvian Times 29, no. 1508 (1969): 11-14.

${ }^{42}$ Regina Horta Duarte, "Zoogeografia do Brasil: Fronteiras nacionais, percursos pan-americanos," Latin American Research Review 49, no. 2 (2014): 68-83; Camilo Quintero Toro, Birds of Empire, Birds of Nation: A History of Science, Economy, and Conservation in United StatesColombia Relations (Bogota, 2012); Jennifer Price, Flight Maps: Adventures with Nature in Modern America (New York, 1999); Mark V. Barrow Jr., Nature's Ghosts: Confronting Extinction from the Age of Jefferson to the Age of Ecology (Chicago, 2009); Ritvo, "Animal Planet"; Gregory T. Cushman, Guano and the Opening of the Pacific World: A Global Ecological History (Cambridge, 2013); Edward D. Melillo, "The First Green Revolution: Debt Peonage and the Making of the Nitrogen Fertilizer Trade, 1840-1930," American Historical Review 117, no. 4 (October 2012): $1028-1060$.

${ }^{43}$ Chris Weathersbee, "Parrot Fever under Control; Imports On," El Paso Herald, November 28, 1968; Maria Buchinger, "Special Latin American Issue," Nature Conservancy News 1, no. 1 (1965), Denver Public Library Conservation Collection, Nature Conservancy/CONS76/ TNC, box 225.

${ }^{44}$ Kelerson Semerene Costa, "Templos de Tânatos, templos de Eros: A exploração da tartaruga nas praias amazônicas," in José Luiz de Andrade Franco, Sandro Dutra e Silva, José Augusto Drummond, and Giovana Galvão Tavares, eds., História ambiental: Fronteiras, recursos naturais e conservação da natureza (Rio de Janeiro, 2012), 261-292; Sharika D. Crawford and Ana Isabel Márquez-Pérez, "A Contact Zone: The Turtle Commons of the Western Caribbean," International Journal of Maritime History 28, no. 1 (2016): 64-80.

${ }^{45}$ Paul V. Pierret and Marc J. Dourojeanni, The Reservation for Vicunas of Pampa Galeras, Its Present and Future Status, report, May 1967, Servicio Forestal y de Caza Instituto de Investigaciones Forestales, Universidad Agraria, box 39, folder 12, James D. Yoakum Papers, Special Collections and University Archives, University of Nevada, Reno.

${ }^{46}$ Marc J. Dourojeanni, "Fundamentos y ejecución del programa de parques nacionales y reservas equivalentes del Perú," Actas II Taller Internacional sobre el Manejo de Áreas Silvestres Parque Nacional de Iguazú, Argentina, 14 enero-3 de marzo 1973, CDC-UNALM.

${ }^{47}$ See correspondence between Peruvian taxidermist Celestino Kalinowski and Colin Campbell Sanborn of the Chicago Field Museum; Field Museum Library, Zoology Corres/ Sanborn 1946-1955/ Folder Kalinowski, 1946. See also the scrapbook compiled by Lucile Quarry Mann of an animal collection trip to South America in 1939; Smithsonian Institution Archives, SIA RU007293, William M. Mann and Lucile Quarry Mann

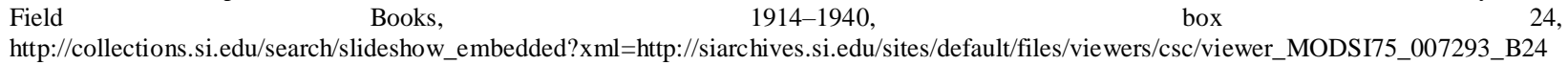
Al01.xml.

${ }^{48}$ Mayer, Ugly Stories of the Peruvian Agrarian Reform, 17-18.

${ }^{49}$ Bernard Grzimek to Rudolf Hofmann, July 12, 1979, FZS; Marc J. Dourojeanni, Crónica forestal del Perú (Lima, 2009), $259-262$.
} 
This is an author-produced, peer-reviewed version of this article. The final, definitive version of this document can be found online at The American Historical Review, published by Oxford University Press. Copyright restrictions may apply. doi: 10.1093/ahr/rhz939

During the next era, the 1968-1975 leftist authoritarian period of General Juan Velasco Alvarado and the military regime, the Peruvian state expanded its capacity for governing nature. A proactive conservation community flourished, with a more efficient and better-financed forestry service. ${ }^{50}$ On the one hand, this comes as no surprise, as revolutionary governments in Mexico, Cuba, and Chile also assumed control over swaths of territory redefined as national resources. ${ }^{51}$ On the other hand, unlike Cuba, where Castro's highly personalized rebel group seized power, or Chile, where a life politician, Salvador Allende, brought socialism through the ballot box, the ascension of a leftwing military government in Peru fits less neatly into familiar Cold War binaries. A standing military expelled a president in order to engage in leftist social engineering. ${ }^{52}$ A process of nationalization ensued whereby entire industries, including fishing, mining, and telecommunications, were brought under state management. Animal conservation earned a small but significant place within these rural development programs and bureaucratic expansionism over natural resources.

Globally, authoritarian actions have long shaped conservation areas, starting with royal hunting reserves and armies patrolling national parks. ${ }^{53}$ Decisions to conserve natural resources are often politically unpopular; thus measures in favor of animals may be more easily implemented by governments that do not answer meaningfully to their citizens. But this does not make nature conservation only authoritarian; conservation as an activity has no clear or consistent political allegiance. What makes restrictive measures appear antithetical to conservation-as opposed to restrictions imposed for ranching, farming, forestry, or other land uses - is the common assumption that conservation exists for, or at least in the name of, the public (which is rarely defined). The case of the vicuña shows that alternative methods of proving conservation's value existed decades before critiques about the troubles of wilderness areas. Conservation laws, wildlife treaties, and management protocols accompanied the rise of a generation of scientists and technicians who had a practical vision for the management of nature for social ends. That is, they expected nature to pay for its place among the rural poor. Modern Peruvian wildlife conservation emerged in an authoritarian political context and began comparatively late, but its proponents were among the first in the world to design conservation with the explicit intention to benefit people living on the same lands.

The authoritarian context and growing scientific expertise facilitated rapid action, but why create and manage a reserve? Because the animals were wild, a reserve simply provided a protectable locale for vicuña ecology to evolve. As Peter Alagona has shown for the United States, efforts to prevent animal extinction became increasingly linked with habitat conservation as ecologists gained a greater understanding of relationships among species. ${ }^{54}$ This was also the case in Peru. A group of biologists resident in Peru began to study the vicuña in the 1960s. Working through the National Agrarian University La Molina, Dourojeanni and Pierret recommended a reserve in several written reports. ${ }^{55}$ Creating reserves far from the country's borders would allow the population to rebound, they argued, and it would also create opportunities for observation and education. ${ }^{56}$ Such a reserve would require an appropriate place for animals to reside unmolested.

The first vicuña reserve, Pampa Galeras, was established in the heart of the animal's historical range, where studies had shown that most of the animals lived. Pampa Galeras was located geographically within the municipality of Lucanas, the least densely populated area of the province of Ayacucho. The 1964 census indicated a population of 81,445 people, or about 4.4 people per square kilometer. Scientists initially believed the area was state-owned, and therefore thought that converting it to a reserve would be simply a matter of purchasing the grazing rights from nearby

\footnotetext{
${ }^{50}$ Dourojeanni, Crónica forestal del Perú, 95-96, 107.

${ }^{51}$ Boyer, Political Landscapes; Thomas Miller Klubock, La Frontera: Forests and Ecological Conflict in Chile's Frontier Territory (Durham, N.C., 2014).

${ }^{52}$ Carlos Aguirre and Paulo Drinot, eds., The Peculiar Revolution: Rethinking the Peruvian Experiment under Military Rule (Austin, Tex., 2017); Hal Brands, Latin America's Cold War (Cambridge, Mass., 2010); Gerardo Rénique, “'People's War,' 'Dirty War': Cold War Legacy and the End of History in Postwar Peru," in Greg Grandin and Gilbert M. Joseph, eds., A Century of Revolution: Insurgent and Counterinsurgent Violence during Latin America's Long Cold War (Durham, N.C., 2010), 309-337; Linda J. Seligmann, Between Reform and Revolution: Political Struggles in the Peruvian Andes, 1969-1991 (Stanford, Calif., 1995).

${ }^{53}$ See examples of authoritarianism in Conrad Totman, The Green Archipelago: Forestry in Preindustrial Japan (Athens, Ohio, 1998); Franz-Josef Brüggemeier, Mark Cioc, and Thomas Zeller, eds., How Green Were the Nazis? Nature, Environment, and Nation in the Third Reich (Athens, Ohio, 2005); Juan Pimentel Igea, El rinoceronte y el megaterio: Un ensayo de morfología histórica (Madrid, 2010); Wilko Graf von Hardenberg, "Act Locally, Think Nationally: A Brief History of Access Rights and Environmental Conflicts in Fascist Italy," in Marco Armiero and Marcus Hall, eds., Nature and History in Modern Italy (Athens, Ohio, 2010), 141-158.

${ }^{54}$ Peter S. Alagona, After the Grizzly: Endangered Species and the Politics of Place in California (Berkeley, Calif., 2013).

${ }_{55}^{5}$ Pérez Ruiz, La saga de la vicuña, 50-51; Hofmann and Otte, Utilización de la vicuña en el Perú.

${ }^{56}$ Dourojeanni, Crónica forestal del Perú, 260; Herre, "El problema de la vicuña," 7; Rudolf K. Hofmann, "Some Considerations Regarding the Increase of Vicuña Population in Pampa Galeras, Ayacucho," report, 1967, CDC-UNA-LM.
} 
This is an author-produced, peer-reviewed version of this article. The final, definitive version of this document can be found online at The American Historical Review, published by Oxford University Press. Copyright restrictions may apply. doi: 10.1093/ahr/rhz939

herders. In March 1965, Dourojeanni and Luis Takahasi went to the proposed site and learned that it belonged to several rural communities, including Lucanas, Saisa, San Cristóbal, Uchuytambo, Santiago, and Tambo Quemado. There were also some parcels of private land in adjacent valleys. ${ }^{57}$

The scientists admitted the difficulty of this situation. Given the legal arrangements in articles 207 and 212 of the constitution, which patronizingly governed rural land, rural communities did not have the authority to make the kinds of agreements the Forestry Service (Dirección General Forestal y de Fauna) would ask of them. The request for a change in land use had to be filed through the Ministry of Labor and Rural Affairs (Trabajo y Asuntos Campesinos), which had final authority. This meant that scientists had to go into a community and explain that they represented a separate branch of the government, different from the ministry that sought to control the communities, but that they would like the community to remove their livestock from their rightful lands for the benefit of the nation. Dourojeanni and Takahasi estimated that about thirty families grazed 6,000 head of sheep and a similar number of other livestock in the proposed reserve. They began conversations with representatives from the community of Lucanas and learned that many of the families did not own the livestock, but herded them for down-valley owners. These representatives indicated that they had observed professional vicuña hunters and were opposed to their presence there. In an October 1965 meeting with nearly 100 residents and all local political representatives (mayor, attorney, secretary), the Forestry Service officials explained the need for the reserve and how it would restructure relationships between communities and wild animals. In exchange for the use of 5,000 hectares, the community members asked for local schools, a medical post, and reforestation on communal lands. ${ }^{58}$ Community members agreed not to interfere with the vicuña grazing on the range with their sheep, llamas, and alpacas, and they removed all permanent corrals from the reserve's core. ${ }^{59}$ Forestry officials initially planned to fence in the reserve, but that did not occur. After much inter-agency wrangling over the next year, the Forestry Service signed an agreement with the community of Lucanas in October $1966 .{ }^{60}$

The proposed benefits to communities that shared the same lands were the most radical feature of the initial formal agreements for vicuña conservation. The director of the Forestry Service, Flavio Bazán Peralta, met in Lima with Lucanas's elected mayor, Amador Martínez Sarmiento, and legal representative, Jorge Espinoza Herrera, to discuss and sign the eight sections of the agreement in front of a notary. ${ }^{61}$ The agreement laid out the terms of use between the Forestry Service and Lucanas. ${ }^{62}$ In return for allowing the Forestry Service to fence the reserved land and "store" (albergará) vicuña there, community land in Lucanas would be reforested, a school would be constructed, opportunities for employment would be made available (meaning the use of community labor within the reserve), and a cooperative would be created for community conservation initiatives. The community would also participate in administering the reserve, with a permanent delegate at Pampa Galeras. ${ }^{63}$ In addition, and in a key provision for securing Lucanas's support, all profits gained from the sale of vicuña wool, after reserve costs were met, would be returned to the community. Because community leaders were invited into the negotiations over Pampa Galeras, the scale of the program allowed the continued coexistence of residents' domesticated animals and the wild vicuña. But this hardly meant harmony.

As with most national programs, the receiving community was deeply divided over the implications of the vicuña conservation program and its distribution of benefits. Most community members worked as subsistence shepherds of sheep and alpaca or as cultivators of potatoes, wheat, corn, beans, and alfalfa. One survey found that less than a quarter of residents were what the state categorized as "economically active." ${ }^{64}$ Restricted to small, isolated, infertile plots of land, campesinos extracted whatever value they could from the highlands and relied economically on domesticated livestock, mainly sheep. Each sheep yielded approximately four kilograms of meat and half a kilogram of wool per year, scarcely enough to cover the resources they consumed. Despite low profits and high environmental degradation,

\footnotetext{
${ }_{57}^{57}$ Pierret and Dourojeanni, "The Reservation for Vicuñas of Pampa Galeras."

${ }^{58}$ Several rounds of negotiations happened over the reserve size, which ranged from 5,000 to 6,500 to 8,000 hectares in the various proposals. Despite some initial reluctance about the size, other communities joined the agreement and extended the protected habitat adjacent to the core reserve to more than 500,000 hectares by 1979 .

${ }^{59}$ Ed Riccuiti, "Vicuña: Troubled Treasure of Peru," Animal Kingdom: The Zoological Society Magazine, New York, June 1982, 12; Edgar Hugo Sánchez Infantas, "El muestreo como alternativa para evaluar poblaciones de vicuñas en Pampas Galeras" (thesis, Universidad Nacional Agraria La Molina, Lima, 1986), CDC-UNALM. Koford recommended the removal of domesticated livestock, but forestry officials saw that as too great a political risk. Pierret and Dourojeanni, "The Reservation for Vicuñas of Pampa Galeras."

${ }^{60}$ Brack, "La conservación y el manejo de la vicuña," 12.

${ }_{61}$ "Convenio de cooperación,” October 17, 1966, CDC-UNALM. See also Pérez Ruiz, La saga de la vicuña, 50-53.

62 "Convenio de cooperación."

${ }^{63}$ Brack, "La conservación y el manejo de la vicuña," 24.

${ }^{64}$ Cueto, Ponce, Cardich, and Rios, "El manejo de la vicuña," 1.
} 
This is an author-produced, peer-reviewed version of this article. The final, definitive version of this document can be found online at The American Historical Review, published by Oxford University Press. Copyright restrictions may apply. doi: 10.1093/ahr/rhz939

residents associated these animals with wealth and success; sheep signified higher social status. ${ }^{65}$ Some herders trained their dogs to attack young vicuña because they viewed vicuña as competing with sheep. Others may have become poachers if they were able to find a way to smuggle vicuña products into the closest and easiest foreign location for export, Bolivia ${ }^{66}$ Residents who viewed the vicuña as a pest interpreted the favoring of this wild animal over their domesticated livestock as futile and even unfair. ${ }^{67}$

Yet other residents acted in support of species survival. Some worked as guards and patrollers or assisted with scientific studies such as taking population censuses of wild animals. At least one campesino lost his life in a shootout with poachers. Most poachers were not from the region. ${ }^{68}$ The communities near Pampa Galeras never constituted a fixed whole with similar demands but represented a heterogeneous group where individuals could pursue opportunities in conservation to acquire new skills or find themselves disadvantaged by changes, including the decline of rangeland quality.<FIG. 4 NEAR HERE>

From the intersection of community practices and new state initiatives, a conviction emerged among government technicians that the vicuña should survive and campesinos should benefit from its survival. For this to happen, larger agreements and international support needed to be in place. The conservation efforts spread regionally when Peru hosted the first technical meeting on vicuña protection in Arequipa in $1969 .{ }^{69}$ Until the flow of pelts into Bolivia stopped, Peruvians felt that they could not fully halt poaching. Recommendations at the meeting ranged from the immediate to the long-term: prohibit all trade in vicuña products, establish reserves and national parks, create a guard school, study economic uses for the animal, foster cultural interchange (training, courses, prizes, work exchanges), and form a permanent committee to enforce accords. This was the first of dozens of intraregional meetings, and it established the vicuña as the premier charismatic megafauna for the region, burdening it with immense possibility as both an animal in need of rescue and a potential source of economic development native to the region. In these actions, Peruvian representatives expressed a vision of conservation that included wildlife as part of the socioeconomic fabric of rural societies.

The 1966 agreement marked the start of the vicuna's recovery and provided the incentive for foreign involvement. International institutions participated in the conservation program initially by funding it. These included Belgian and German technical cooperation agencies, the Nature Conservancy, and later the World Wildlife Fund and the Frankfurt Zoological Society. ${ }^{70}$ Simultaneously, two German scientists, Kai-Christian Otte and Rudolf Hofmann, first came to Peru with the Food and Agricultural Organization of the United Nations (FAO) in connection with a forestry project. The men began studying Amazonian populations of black caiman, but the very real possibility of extinction led them to the vicuña. Hofmann, a skilled field biologist, was appointed by Dourojeanni and funded by the Frankfurt Zoological Society and the World Wildlife Fund to manage the vicuña program within the Forestry Service. Later, the German Agency for Technical Cooperation (GTZ) paid for him to continue this work. These agencies provided significant funds to maintain the vicuña project, including the construction of the reserve buildings and the cost of equipping employees. ${ }^{71}$

In addition to the external organizations providing financial support, international governance structures played a role, especially the Convention on International Trade in Endangered Species (CITES). CITES was signed by eighty parties, including Peru, in Washington, D.C., on March 3, 1973, and it remains among the most successful voluntary frameworks for conservation. ${ }^{72}$ The standing committee maintains a list of endangered species, which it classifies into categories known as appendices. Appendix One, the strictest, prohibits all international commercial trade in a particular species; Appendix Two allows some highly regulated commercial trade; and Appendix Three promotes

\footnotetext{
${ }^{65}$ Ibid., 1.8.

${ }^{66}$ Koford, "The Vicuña and the Puna," 213.

${ }^{67}$ Cueto, Ponce, Cardich, and Rios, "El manejo de la vicuña," 16.

${ }^{68}$ Hofmann and Otte, Utilización de la Vicuña en el Perú, 9. Koford notes that because of the expense and the difficulty of acquiring or owning guns, few Indians had one, which made them less likely to be poachers; The Vicuña, 214. See also "Acta de la sesión del comité de protección a la naturaleza del día jueves 17 de diciembre de 1964,” 30-31, Boletin del Comite Nacional de Protección a la Naturaleza 19 (December 1964), noting sources of contraband in vicuña wool from the Bolivian Embassy.

${ }^{69}$ Brack, "La conservación y el manejo de la vicuña," 11. The regional meeting was called the Primera Reunión de Técnicos Representantes de Argentina, Bolivia, y Perú para el Estudio y Protección de la Vicuña, and it led to the signing of a bi-national agreement for vicuña conservation in 1969, known as the La Paz Agreement. An initial cooperation meeting was held December 10-12, 1964, while the first technical conference was held in Lima in December 1971.

${ }^{70}$ Brack, "La conservación y el manejo de la vicuña," 9.

${ }^{71}$ Funds were distributed on a per-project basis. FZS, Vicuña file, Projekte ZGF-Nr. 831/78.

${ }^{72}$ To date there are 183 signatories. The vicuña became one of the early successes of the policy; see Lyster, International Wildlife Law, chap. 5.
} 
This is an author-produced, peer-reviewed version of this article. The final, definitive version of this document can be found online at The American Historical Review, published by Oxford University Press. Copyright restrictions may apply. doi: 10.1093/ahr/rhz939

monitoring the species. As with all international treaties, the enforcement mechanisms are only as viable as the member parties' willingness to comply with them. The vicuña was listed immediately in Appendix One, with the idea that once the population recovered, commercialization would be reintroduced to benefit Lucanas and the reserve. ${ }^{73}$

It is important to see these international developments as occurring in sync with evolving national institutions. Attributing causation only to the international interests ignores the full range of relationships at work. Debates over vicuña management show that while foreign experts had roles, they were often critically shaped by domestic actors. As Mark Carey argues regarding mountaineers in Peru, one cannot assume Europeans were the only ones with agendas; Peruvians routinely used the influence of foreigners to pursue their own objectives. ${ }^{74}$ The coordinated approach - create a territorial reserve with community participation, engage in scientific study of the species, and prohibit international commerce-quickly achieved the goal of vicuña recovery and produced new entanglements between humans and wild animals. Different levels of human organization came together to create the reserve, but within it, vicuña organized themselves strategically to maximize their own population.

In response to their new reserve, vicuña populations spread out across Pampa Galeras and revealed facets of their own social structure to biologists now scrambling to understand them. The majority of vicuña live most of their lives in family groups composed of a single male of reproductive age and four to six females and their offspring. Such breeding groups compete for preferred territories because vicuña are sedentary rather than migratory animals. Alpha males select and defend territories and protect their harems against predators and other males. The male regulates the number of animals within his family group by accepting or rejecting outsiders and expelling juveniles. ${ }^{75}$ Such a configuration leaves significant numbers of unattached males, which band together in bachelor troops until they are able to compete for females. Lone vicuña are almost always senile. ${ }^{76}$ Social organization is flexible, not fixed, and can change across seasons, populations, and habitats in order to maximize reproductive success. The proximate factors for such success were put into place when conservationists created the reserve at Pampa Galeras.

It is unclear how many family groups existed in total, but the vicuña population at Pampa Galeras increased every year between 1967 and 1978, when it stood at between 36,202 and 38,643 animals. ${ }^{77}$ Females produce one cria per year, following a gestation period of about eleven months. A clear relationship exists between reproductive success and time spent grazing. One study found that gestating and lactating vicuña spend over 90 percent of their waking hours grazing. With the animals' greater access to secure pasture and a reduced number of predators, reproductive success increased exponentially. ${ }^{78}$ In less than a decade of state-sponsored conservation measures, the vicuña's survival seemed secure. This population increase of nearly 30 percent each year attested to the efficacy of the reserve, trade restrictions, and governmental intervention. In December 1978, the Ministry of Agriculture formally created a new autonomous, nationally funded project, the Special Project for the Rational Use of the Vicuña (Proyecto Especial de Utilización Racional de la Vicuña [PEURV]), to steward conservation efforts. ${ }^{79}$ The goals of PEURV centered on the utilitarian value of the animal and included improving the natural grasslands, putting marginal lands into "production" by cultivating vicuña on them, and "rationally utilizing" the increased population by "biannually shearing adult vicuña and culling excessive numbers of juvenile males." ${ }^{80}$ Up until that point, there had been a piecemeal approach to the management and budget for vicuña conservation; the establishment of PEURV signified the solidity and success of state-based conservation.

But animal populations are hardly static. By 1979, the increase of animals had dropped to a slower rate, and rather than stabilize, conditions in the reserve began to deteriorate. Agronomists Arturo Flores and Efrain Malpartida found that vicuña thrive when they are afforded 1.85 hectares of grazing area per animal, but competition in the reserve, both from higher numbers of vicuña and from domesticated animals that had never been removed, decreased that stocking

\footnotetext{
${ }^{73}$ Brack, "La situación actual de la población de vicuñas," 1980; Dourojeanni, Crónica forestal del Perú, 211.

${ }^{74}$ Mark Carey, "Mountaineers and Engineers: The Politics of International Science, Recreation, and Environmental Change in Twentieth-Century Peru," Hispanic American Historical Review 92, no. 1 (2012): 107-141.

${ }^{75}$ Franklin, "The Social Behavior of the Vicuña," 477. Franklin notes five principal social groups: permanent territorial family groups; marginal territorial family groups; mobile family groups; male groups; and solo males.

${ }^{76}$ Rudolf K. Hofmann, "La población de las vicuñas en Pampa Galeras," Instituto de Investigaciones Forestales: Sección: Vida Silvestre, Informe Técnico No. 22, 1969, CDC-UNALM.

${ }_{77}^{77}$ Brack, "La conservación y el manejo de la vicuña," 9; Eltringham and Jordan, "The Vicuña of the Pampa Galeras National Reserve," 280

${ }^{78}$ Paul C. Bosch and Gerald E. Svendsen, "Behavior of Male and Female Vicuña (Vicugna vicugna Molina 1782) as It Relates to Reproductive

Effort," Journal of Mammology 68, no. 2 (1987): 425-429.

${ }^{79}$ Dourojeanni, Crónica forestal del Perú, 261.

${ }^{80}$ Ministerio de Agricultura, Proyecto para la Utilización Racional de la Vicuña Silvestre, Hoja Informativa, 1977, CDC-UNALM.
} 
This is an author-produced, peer-reviewed version of this article. The final, definitive version of this document can be found online at The American Historical Review, published by Oxford University Press. Copyright restrictions may apply. doi: 10.1093/ahr/rhz939

rate to less than .75 hectares per animal by $1980 .{ }^{81}$ Satisfaction regarding the effectiveness of the project quickly devolved into conflict over what would come next. Internal debates about how to enact, enforce, and finance conservation created explosive rifts within a small group of national figures. General and widespread agreement on the initial conservation measures gave way to fierce disputes over the strategy and orientation for the next steps. The discord reveals the sophistication of Peruvian conservationists, who were divided over two issues: how to pay for vicuña conservation and what role managers should take in resolving the population issues.

These debates are best understood in the context of competing modes of conservation thought. Peru, in the 1960s, experienced the emergence and confluence of distinct philosophical orientations toward conservation that converged on the issue of the vicuña because of the crisis of potential extinction. Some countries have spread conversations about conservation over centuries of debate. In the United States, for example, providential, progressive, romantic, and ecological perspectives on the land have come in successive waves. ${ }^{82}$ In Brazil and Mexico, romantic or scientific perspectives on nature formed disconnected generations rather than continuous legacies augmenting environmentalism. ${ }^{83}$ A similar disjuncture occurred with guano bird conservation in coastal Peru between 1909 and 1965 , as the conservation value of birds gave way to the economic importance of fisheries. ${ }^{84}$ The advantage of the late emergence of dedicated environmental defenders was that scientific and social advances - rather than solely economic priorities - could be incorporated into their discussions. Studies of animal ecology and concerns for resident communities directly influenced state approaches to conservation. The disadvantage was the severity of the vicuña crisis.

The prospect that vicuña might entirely disappear contributed to an intense conflict over how to manage the increased population within the reserve. Two approaches to this conflict-aristocratic and bureaucratic - illuminate the ways contrasting visions for conservation clashed over the vicuña. ${ }^{85}$ On the aristocratic side, a small, privileged class of actors advocated conservation as a symbolic assertion of Peruvian sovereignty and an expression of a highly emotional affinity for the animal. This was a mostly closed group of people with vast personal and financial resources who leaned toward nationalist or patriotic arguments about the animals' intrinsic worth, dramatized the population collapse, and advocated translocation, an expensive option, as a method of controlling the reserve population. With disproportionate social and political influence, this traditionally powerful group could act without evidence, logic, or restraint. Felipe Benavides Barreda (1917-1991) best characterizes this approach. Born and raised in urban Lima, Benavides traced his heritage to Spanish viceroys, recent presidents, and international businessmen. ${ }^{86}$ In 1938, while attending the London School of Economics, he noted the high-priced vicuña fiber jackets and sweaters for sale in upscale shops, which he claimed motivated his later actions on behalf of the animals. ${ }^{87}$ By contrast, the bureaucratic approach to conservation was marked by a scientific, technical, and rational orientation based on austere observations and direct evidence. This group was dynamic and growing, and it privileged expertise gathered on-site. Perhaps the most representative figure of this mode of conservation thought was Antonio Brack Egg (1940-2014). Brack was the grandson of German immigrants to a remote jungle community, Oxapampa, where he was born. Raised on a farm, he

\footnotetext{
${ }^{81}$ Flores and Malpartida, "Estudio de los pastizales en Pampa Galeras," 7. They also note that few diseases infect both domesticated and wild animals, and those that do are rarely fatal.

82 Jedediah Purdy, “American Natures: The Shape of Conflict in Environmental Law," Harvard Environmental Law Review 36 (2012): $169-228$.

${ }^{83}$ José Augusto Pádua, Um sopro de destruição: Pensamento político e crítica ambiental no Brasil escravista, 1786-1888 (Rio de Janiero, 2002); José Luiz de Andrade Franco and José Drummond, "História das preocupações com o mundo natural no Brasil: Da proteção à nature za à conservação da biodiversidade," in Franco, Silva, Drummond, and Tavares, História ambiental, 333-366; Boyer, Political Landscapes; Simonian, Defending the Land of the Jaguar.

${ }^{84}$ Gregory T. Cushman, “The Most Valuable Birds in the World': International Conservation Science and the Revival of Peru's Guano Industry, 1909-1965," Environmental History 10, no. 3 (2005): 477-509.

${ }^{85}$ To the larger process of conservation, one could add campesino approaches, poachers' views, the perspectives of those working for international organizations, and more, but for the discussion here about the management conflict, these views are less immediately relevant because these groups were not afforded a significant role in the design and enactment of policies or within the subsequent public debate. For example, rather than having the opportunity to consistently participate in designing national-level management protocols, members of communities such as Lucanas had policies enacted for them rather than with them. Local or regional support and dissent are beyond the scope of this article, because without national-level trade restrictions and reserve enforcement, it is unlikely that local or regional action alone could have saved the animal.

${ }^{86}$ Wilfredo Pérez Ruiz, "Felipe Benavides: Aportes y vigencia de su obra," unpublished ms., Lima, December 2001, author's collection. Benavides was the nephew of Óscar Benavides Larrea (president 1914-1915 and 1933-1939) and the son of Alfredo Benavides Diez Canseco, a diplomat and second cousin of Fernando Belaúnde Terry (president 1963-1968 and 1980-1985).

87 "Felipe Benavides Barreda," Sociedad Zoológica del Perú, n.d. During Benavides's father's diplomatic service to England, it is possible that Felipe attended meetings of the Society for the Preservation of the Fauna of the Empire (later the Fauna Preservation Society) in London. See Adams, Against Extinction, especially 22-25 and 43-47.
} 
This is an author-produced, peer-reviewed version of this article. The final, definitive version of this document can be found online at The American Historical Review, published by Oxford University Press. Copyright restrictions may apply. doi: 10.1093/ahr/rhz939

developed an affinity for animals that eventually led him to a Ph.D. in natural sciences. ${ }^{88}$ Because of the widespread interest in the vicuña's survival, these visions clashed quite publicly over the issue of animal overpopulation. As a result, noblesse oblige and managerial visions competing within the same society shaped and twisted the shared goal of species conservation, magnifying the ways in which privilege structured new relationships to wild animals. $<$ FIG. 5 NEAR HERE>

As social groups, elites and scientists could engage a larger public in conserving wild animals. Benavides pursued his own interests and popularized conservation in part because he could afford to do so. His prominent profile indicated the strong history of patronage networks and the persistence of oligarchic influence, despite meaningful and significant progress made on behalf of democratizing political movements, especially in the $1960 \mathrm{~s} .{ }^{89}$ As much as he claimed to champion the community around Pampa Galeras, his own life represented wealth and power centered in Lima. Calling himself "Mr. Vicuña," Benavides used wildlife to promote his own image more than to reflect the animal's natural character. By contrast, Brack represented the emergence of natural resource management, a concrete manifestation of the intersection between state-building and conservation, also centered in Lima but with crucial satellites nationwide. He was part of the first group of government scientists who made conservation a career. Dozens of domestic scientists, many with world-class educations, became administrators, bringing resource management out from back-door, upperclass channels. Despite the authoritarian political context, the creation of state-based institutions democratized conservation in important ways. Vicuña conservation began as a public good managed by and developed through centralized national institutions. It was not radical enough to meaningfully incorporate perspectives from Lucanas residents, though it did crucial work. In addition to providing a degree of stability, the state-funded activities, such as PEURV, opened possibilities for non-wealthy people to make a career out of valuing animals in the wild. The return benefit to society and the natural world was the survival of a charismatic animal in its historical landscape. But it might have included even more.

The crux of the divisive management conflict came down to one question: Who would determine whether the vicuña had recovered enough to begin harvesting them? The bureaucrats had always planned to cull the population once their numbers stabilized. With fast recovery, culling seemed not only achievable but, in their view, indispensable. They offered three additional arguments in favor of culling the excess population of vicuña. The first explicitly addressed the ecological landscape: the area had been marked by excessive drought, with less than half the normal precipitation in the reserve for three out of four years, which had compromised the quality of the grassland.$^{90}$ The second argument echoed the environmental context of population pressure by pointing out that in 1973, the population of vicuña had skyrocketed and the number of domestic grazing animals had also increased. ${ }^{91}$ This animal "overload" meant the vicuña population had now begun to increase more slowly, with birth rates cut in half. ${ }^{92}$ By contrast, the final argument was social: scientists argued that the local community had been promised returns on their stewardship of the animals. Harvesting would allow the use of animal products before conditions caused them to go to waste. Relocation to other protected areas had also been planned, but it was not intended to take the place of culling. The managers articulated these ecological, demographic, and social reasons in a series of reports and began preparations for the cull that the management plan and existing laws called for.

In more than forty reports, the scientists discuss the social characteristics of the vicuña and rarely talk about the animals beyond their particular social roles-family groups, bachelor troops, and the like. Sensitivity to the vicuña's social structure informed the recommended actions for culling the population. For instance, rather than shoot animals randomly as encountered, scientists recommended that bachelor troops be eliminated first, and then entire family groups. This would prevent disruption caused by inadvertently removing the male heads from family groups, leaving females unprepared to defend themselves, and it further allowed for social dynamics to take over by ceding the territory

\footnotetext{
${ }^{88}$ Antonio Brack Egg, interview with author, June 27, 2013, Lima, Peru. Other individuals played significant roles in the management process, especially Marc Dourojeanni and Carlos Ponce del Prado, both of whom provided the intellectual rationale for vicuña conservation and supervised Brack. I focus on Brack here because of the ample documentation as well as the fact that he was not of the highest rank yet remained consequential. ${ }^{89}$ Rénique, “'People's War,' 'Dirty War”'; Billie Jean Isbell, To Defend Ourselves: Ecology and Ritual in an Andean Village (1978; repr., Prospect Heights, Ill., 1985); Christine Hunefeldt and Misha Kokotovic, eds., Power, Culture, and Violence in the Andes (Brighton, UK, 2009); Heilman, Before the Shining Path; Miguel La Serna, "Murió comiendo rata: Power Relations in Pre-Sendero Ayacucho, Peru, 1940-1983," A Contracorriente 9, no. 2 (2012): 1-34.

${ }^{90}$ Brack, "La conservación y el manejo de la vicuña." Annual precipitation measurements were $735 \mathrm{~mm}$ in 1973, $240 \mathrm{~mm}$ in 1974, $275 \mathrm{~mm}$ in 1975, 515 mm in 1976, and $350 \mathrm{~mm}$ in 1977. See also Rudolf K. Hofmann, Kai-Christian Otte, Carlos F. Ponce, and Manuel A. Rios, El manejo de la vicuña silvestre, 2 vols. (Eschborn, 1983).

${ }^{91}$ Brack, "La situación actual de la población de vicuñas," 1980, 4; Hofmann and Otte, "El censo de la vicuña silvestre."

${ }^{92}$ Dourojeanni, Crónica forestal del Perú, 259; Antonio Brack Egg, "La situación actual de la vicuña en el Perú y alternativas para su manejo," 1979, CDC-UNALM; Hofmann and Otte, "El censo de la vicuña Silvestre."
} 
This is an author-produced, peer-reviewed version of this article. The final, definitive version of this document can be found online at The American Historical Review, published by Oxford University Press. Copyright restrictions may apply. doi: 10.1093/ahr/rhz939

to another intact family group. While this attention conveys a particular way of understanding the animals and should not be thought of as disinterested, it remains remarkably consistent throughout the reports and presents a larger context of the territory, animal behavior, and changes over time.

The official government recommendation was that the population be reduced by 12,000 animals, with 6,000 to be transported and 6,000 to be killed..$^{93}$ The meat would be sold, and the wool would be stored in Pampa Galeras. ${ }^{94}$ In December 1977, the cull began. Precision firearms were used to selectively sacrifice 210 unattached males in bachelor troops. Two resident biologists, Hofmann and Otte, directed the process on-site using the forestry police team they had trained, which included mainly laborers from Lucanas. Experts and institutions such as the World Wildlife Fund and the International Union for the Conservation of Nature supported the cull. The Peruvian government was now poised to fulfill its promises and make sustainable use of the vicuña products. But Benavides and his followers had another perspective on what recovery should look like.

The aristocratic response to the question of overpopulation was primarily to question the notion of overpopulation. Benavides's social position gave him access to national media and an international community willing to intervene. They began a campaign designed to inflame popular objections to killing vicuña and to advocate that vicuña be transported to other regions. He hired a South African biologist, Keith Eltringham, to come to Peru and conduct an aerial census to demonstrate the fallibility of the population estimates that had been methodically carried out for ten years. ${ }^{95}$ The census, the first of its kind in the reserve, was conducted at an altitude too distant to see many animals. With Benavides himself in the plane, barely a pretense of objectivity remained. Even the author conceded the survey's problematic nature, noting that "[t]he aerial total has been dismissed as useless, but it serves to cast doubt on the ground totals given by Brack." 96 And yet, in a high-profile international meeting and its published proceedings, Eltringham's few hours in the reserve occupied as much space as the explanation from the scientists who had lived in the reserve for more than a decade. Another aerial survey conducted in 1980 concluded that Eltringham had missed more than two-thirds of the animals and confirmed the ground survey data. ${ }^{97}$ Nevertheless, publicity ballooned among more radical protection groups like the International Fund for Animal Welfare, which printed pamphlets entitled Will the Vicuña Survive?, the cover of which pictured a solitary male surveying the horizon. This image misrepresented the animal's sociobiology as fully as it misconstrued the immediate danger of extinction. $<$ FIG. 6 NEAR HERE>

As conservationists in Lima debated success and recovery, vicuña continued to change the landscape of Pampa Galeras in familiar and revealing ways. For instance, vicuña communally defecate on large dunghills. These piles of excrement heavily influenced vegetation patterns in the reserve. In one of nature's more prophetic ironies, the grasses most sought after by vicuña grew nearest to their dung piles. ${ }^{98}$ William Franklin, a graduate student from Utah State University, noted in 1971 that as vicuna returned, alternating strips of vegetation on slopes became a striking feature of the landscape. ${ }^{99}$ These strips derived from the downhill washing of organic matter, accelerated by violent summer rains, which enhanced plant succession by creating narrow but densely vegetated belts that in turn became favored sites for grazing.

Dunghills serve social as well as ecological purposes for vicuña. Males stand atop the miniature peaks to examine their territory and posture to other males. The heaps of excrement, one or two feet high, increase a male's stature just enough to satisfy his social need to defend his family group. Over time, posturing behavior clearly defined separate territories in the reserve according to the animals' interpretations of the landscape. Scientists frequently observed two family groups grazing tranquilly a few meters apart, with each on its own side of a mutual territorial boundary. If a group member wandered, it was promptly chased back to its own territory by the opposing group's male. ${ }^{100}$ Such

\footnotetext{
${ }^{93}$ Antonio Brack Egg, Domingo Hoces, and Justo Sotelo Huamán, "Situación actual de la vicuña en el Perú y acciones a ejecutarse para su manejo durante el año 1981," (Lima: Ministerio de Agricultura y Alimentación, Proyecto Especial Utilización Racional de la Vicuña, January 1981).

${ }^{94}$ Dourojeanni, Crónica forestal del Perú, 260.

${ }^{95}$ Hofmann and Otte, Utilización de la vicuña en el Perú; Manuel Ríos and Augusto Tovar, "Informe relativo al reporte sobre un conteo aéreo de vicuñas en la reserva nacional de Pampa Galeras y áreas colindantes," report by professors at UNALM, 1980, CDC-UNALM.

${ }^{96}$ Eltringham and Jordan, "The Vicuña of the Pampa Galeras National Reserve," 280.

${ }^{97}$ M. Norton-Griffiths and H. Torres Santibañez, "Evaluation of Ground and Aerial Census Work on Vicuña in Pampa Galeras, Peru: Results of a WWF/IUCN Evaluation Mission, 17 September-7 October 1980," WWF/IUCN report to the Government of Peru, December 1980, CDC-UNALM, online at https://portals.iucn.org/library/node/10489; Jane C. Wheeler and R. Domingo Hoces, "Community Participation, Sustainable Use, and Vicuña Conservation in Peru," Mountain Research and Development 17, no. 3 (1997): 283-287, here 284.

${ }^{98}$ Koford, The Vicuña, 159.

${ }^{99}$ Franklin, "Contrasting Socioecologies of South America's Wild Camelids," 591.

${ }^{100}$ Ibid., 600.
} 
This is an author-produced, peer-reviewed version of this article. The final, definitive version of this document can be found online at The American Historical Review, published by Oxford University Press. Copyright restrictions may apply. doi: 10.1093/ahr/rhz939

boundaries - visual, ecological, and performed — are difficult for humans to see or to interpret correctly without longterm observation of the sort that field biologists accumulate. The existence of these relationships and boundaries made the removal of animals difficult and disruptive in ways that only a few technicians, and the vicuña, understood.

Human modes of asserting intellectual authority over the vicuña reverberated in national debates about the next steps. After claiming that conditions were not dire within the reserve and that the population was not ready to harvest, Benavides argued that culling the animals and selling the wool would "turn a national reserve of endangered species into a game farm." ${ }^{101}$ Benavides's exact motivations for attacking the harvest on the eve of its fulfillment were likely personal; in May 1977 he had declared the cull the apogee of conservation success. ${ }^{102}$ But over the next few years he marshaled a cadre of journalists to promote the animal's intrinsic value and deconstruct the scientific reports and arguments in ways that warped views of the long-term project by reinterpreting the strategic animal harvest as casual annihilation. Most dramatically, in an article titled “¿Pampa de Concentración?,” Benavides insinuated that Brack and the German technicians Otte and Hofmann were running a concentration camp where they sacrificed vicuña. ${ }^{103}$ His accusations seethed with anti-German sentiments and downplayed his own British connections. Benavides and journalists misrepresented the animals' behavior by isolating individuals and discussing the slaughter of pregnant females as particularly egregious rather than noting the predictable social structure and its importance for the animals' health and security. The repetition of personal attacks highlighted Benavides as the heroic savior of the national animal while simultaneously dismissing the breadth, sophistication, and rapid development of a national conservation system that was able to create and administer protected areas and still keep community rights in mind.

As an alternative to culling, relocating the animals was expensive, unpredictable, and perhaps cruel. Costing at least \$200 per animal for labor, transport, tranquilizers, food, and supervision, simply moving excess vicuña proved easier said than done. ${ }^{104}$ Transferring wild animals, especially those with deep territorial instincts, wreaks havoc on their social structure because of the potential to separate family groups and disrupt marked territories. In addition, rather than enabling conservation to pay resident communities for its presence on the land, relocating vicuña increased costs dramatically.

Bureaucratic and aristocratic wrangling over vicuña management derailed the intended social ends for the project on the eve of its fulfillment. Some animals were culled, some were transferred, and some starved in deteriorating conditions. The plan to return the proceeds from harvested wool to the community was not fulfilled because of the halted cull. By 1980, Benavides's dogmatic and extreme view triumphed over the firmly evidenced scientific and technical project. A cadre of experts steeped in on-the-ground experience as well as informed research could not sway public opinion in the same way an elite philanthropist did. His dramatic arguments for the precious animals influenced ministers and other authorities as well. ${ }^{105}$ Translocation or ritual live shearing remained the only politically viable options because transporting charismatic animals appealed to outsiders more than hunting them to provide for highlanders. The project would be further disrupted by the coming war.

Although they can hardly be considered passive animals, vicuña spend more than half of their lives lying down. They rest, sleep, and copulate prostrate with their legs tucked underneath. All vicuña lie down during periods of heavy rain and hail. ${ }^{106}$ They frequently bend their necks behind their forefeet, likely to guard their throats against predators as they sleep. Such positions are also thought to help them endure cold nights and frigid winds. ${ }^{107}$ Within vicuña's socially negotiated territories, the animals prefer to graze downslope, where moister and deeper soils accumulate, and sleep upslope, where they can better see approaching threats. Much like vicuña who lie in repose anticipating of a threat they cannot see, Peruvian society rested quietly while the armed insurgency developed support in the countryside. Thus a parallelism between prostrate animals and a prone civil society reveals the vulnerability and suffering brought to both by the Shining Path.

\footnotetext{
${ }^{101}$ Felipe Benavides, "From the Incas to C.I.T.E.S.," paper presented at the 3rd World Wilderness Congress, Inverness and Findhorn, Scotland, October 8-15, 1983.

${ }^{102}$ Cited in Brack "La conservación y el manejo de la vicuña"; Dourojeanni, Crónica forestal del Perú.

${ }^{103}$ Benavides quoted in “¿Pampa de Concentración?," Caretas (Lima), June 16, 1979.

${ }^{104}$ Riccuiti, "Vicuña."

${ }^{105}$ See legislation and discussion in Sahley, Torres, and Sanchez, "Neoliberalism Meets Pre-Columbian Tradition."

${ }^{106}$ Bosch and Svendsen, "Behavior of Male and Female Vicuña," 427.

${ }^{107}$ Franklin, "The Social Behavior of the Vicuña."
} 
This is an author-produced, peer-reviewed version of this article. The final, definitive version of this document can be found online at The American Historical Review, published by Oxford University Press. Copyright restrictions may apply. doi: 10.1093/ahr/rhz939

By the mid-1980s, nearly as quickly as it had risen to a matter of national debate, the issue of culling vicuña became a theoretical problem and an intellectual exercise subverted to more immediate human conflicts. Lucanas and Ayacucho were overrun during the Shining Path insurgency, which seemed to erupt everywhere overnight. Belaúnde's reelection to the presidency in 1980 was supposed to mark a return to democracy; the Shining Path dramatically derailed the transition. Insurgents had slowly gathered dynamite from mining sites around the country and amassed an artillery force capable of symbolic and strategic strikes, such as against electricity towers and banks. ${ }^{108}$ The army retaliated, and the resulting internal war killed more than 69,000 Peruvians before its resolution. Scholars have made excellent progress in recent years examining the choices available to rural peoples within this conflict and the alternatives they pursued, usually grounded in specific local power relations and social antagonisms. ${ }^{109}$

The political crisis decimated Ayacucho and halted vicuña conservation. Dourojeanni left the government, Hofmann retired, Brack resigned, PEURV collapsed, and the vicuña plan was dropped. The army deactivated the reserve guards who had been recruited from the Lucanas community and trained to patrol the reserve. Their removal infuriated many community members and reduced the reserve's capacity to effectively protect the animals. ${ }^{110}$ Soon thereafter, the reserve buildings were bombed, and the scientists and managers abandoned the locale altogether. ${ }^{111}$ Subsequently, Shining Path guerrillas attacked the community of Lucanas, burning government buildings and stores and stoning business and political leaders. By late 1987, the village was nearly abandoned. ${ }^{112}$ Pampa Galeras was officially closed in 1990, creating a situation conducive to poaching and contraband.

Once again, the vicuña figured as a nationalist and political symbol in this broader conflict. The novelist and failed 1990 presidential candidate Mario Vargas Llosa employed the animals as a metaphor for the extreme depravity of the guerrillas. His 1993 novel A Death in the Andes includes a character, Pedro Tinoco, with severe mental difficulties who lives among vicuña in Pampa Galeras. Shining Path insurgents enter the reserve and slaughter vicuña, then torture the simple man by slowly burning him. ${ }^{113}$ Vargas Llosa's portrayal reflects an interpretation of the Shining Path's brutality that ignores the atrocities of the retaliating army and, more importantly, shows how indigenous peoples and their assumed animals have been constructed by politicians as victims residing outside of national society, not quite capable of handling integration, and in need of intervention. ${ }^{114}$ In the novel, the animal itself serves as a heady symbol whose value was intended to transcend relations among people. Instead, conservation efforts remade the ways various social groups related to wild animals.

As for Pampa Galeras, the Shining Path resolved the debate over culling vicuña by removing the state's presence and thus erasing the barriers to exploitation. Doing so released the painstakingly protected animals onto a clandestine market that privatized profits from the state-funded project. Once the reserve was abandoned, poachers could harvest vicuña at will and hoard or illegally market their spoils. And they did. This breakdown resulted in the elimination of between 30,000 and 50,000 animals in the reserve, creating a population decline of 30 percent over the next three years. ${ }^{115}$ When population censuses in the reserve resumed after a decade, the totals showed that virtually no growth had occurred. Nationally, there were 66,559 vicuña in 1994, but according to projections, there should have been $250,000 .{ }^{116}$ The culling of vicuña, which scientists had recommended to fulfill their utilitarian vision of conservation, did happen, but not under the circumstances they had chosen. One interpretation might hold that the removal of conservation protections during the Shining Path insurgency constituted an artificial experiment that demonstrated the importance of national resource management. Once these were removed, vicuña poaching returned. Rather than

\footnotetext{
${ }^{108}$ Abimael Guzman, a professor at the National University in Huamanga, Ayacucho, catalyzed followers, mainly of university students and peasants, into a cohesive movement. The attack on the village of Chuschi marked the Partido Comunista del Perú-Sendero Luminoso's emergence on May 17, 1980. La Serna, "Murió comiendo rata," 2; Gorriti, The Shining Path, 76.

${ }^{109}$ Deborah Poole and Gerardo Rénique, "The New Chroniclers of Peru: US Scholars and Their 'Shining Path' of Peasant Rebellion,” Bulletin of Latin American Research 10, no. 2 (1991): 133-191; La Serna, The Corner of the Living; Heilman, Before the Shining Path.

${ }^{110}$ Ricciuti, "Vicuña"; Rick Telander, "Riding Herd on Peru's Vicuñas," International Wildlife 11, no. 3 (1981): 36-43.

${ }^{111}$ Brack, "La conservación y el manejo de la vicuña."

${ }^{112}$ Matt Moffett, "Despues de Sendero."

${ }_{113}$ Mario Vargas Llosa, Death in the Andes, trans. Edith Grossman (New York, 1996), especially 36-45.

${ }^{114}$ Paulo Drinot, "The Meaning of Alan García: Sovereignty and Governmentality in Neoliberal Peru," Journal of Latin American Cultural Studies 20, no. 2 (2011): 179-195; Gerardo Rénique, "Law of the Jungle in Peru: Indigenous Amazonian Uprising against Neoliberalism," Socialism and Democracy 23, no. 3 (2009): 117-135; Cecilia Méndez G., "De indio a serrano: Nociones de raza y geografía en el Perú (siglos XVIII-XXI)," Historica 35, no. 1 (2011): 53-102.

${ }^{115}$ Moffett, "Despues de Sendero"; Sergio Carrasco and Marco Zileri, "Negocio redondo," Caretas, October 27, 1994. By contrast, the number of animals in the reserve increased to 90,000 by 1997; Pablo Grimberg, "Disparos sin reserva," Caretas, July 7, 1978.

${ }^{116}$ Sergio Carrasco and Marco Zileri, "Estado de alerta," Caretas, October 27, 1994.
} 
This is an author-produced, peer-reviewed version of this article. The final, definitive version of this document can be found online at The American Historical Review, published by Oxford University Press. Copyright restrictions may apply. doi: 10.1093/ahr/rhz939

conservation's rewards being funneled through the government bureaucracy and out to Lucanas, unscrupulous individuals, enterprising hunters, and clandestine traders pocketed the riches, effectively but illegally privatizing public patrimony.<FIG. 7 NEAR HERE>

And yet, conservation regained its appeal. After the Shining Path no longer posed a threat, the animal and its rescue were reinvented to fit a neopopulist and neoliberal political moment. Using the skeleton of the Pampa Galeras reserve, President Alberto Fujimori (1990-2000) showcased his state philosophy by reestablishing the reserve and rebuilding its infrastructure. In 1993, his government renamed it the Pampa Galeras Bárbara D'Achille National Reserve in memory of an environmental journalist who was mercilessly killed by the Shining Path. But more than change, Fujimori's resuscitation of the reserve marked continuity. The reserve, and the state-based scientific and bureaucratic infrastructure behind it, reinforced the conservation measures that had led to successful animal population increases. In a photograph that captures this transition, Fujimori holds a baby vicuña tightly across his chest. Dressed in an enormous woolen poncho and a chullo, a traditional woolen hat with tassels and ear flaps, he stands in the center of a crudely built wire holding pen full of dozens of wild animals herded together for shearing. The pen is surrounded by campesinos packed against the fence more tightly than the animals and holding national flags or signs celebrating their community. Fujimori's position in the center of the picture and his stature invoke an Inca ruler who alone had the authority to wear vicuña wool in Inca times. This symbolism used the deep past in a nod toward a renewed conservation strategy.

To acquire wool in pre-Columbian times, the Inca ordered that vicuña be rounded up and shorn twice a year in a process called a chaccu. ${ }^{177}$ Versions of the ritual event persisted after the conquest, including one chronicled by the Swiss naturalist Johann Tschudi in $1840 .{ }^{118}$ Tschudi explained that one man from each family gathered stakes, rope, and rags. Using ropes, participants staked out a circular space covering about half a league and tied colored rags to the ropes that fluttered in the wind and frightened the animals towards the center. Men, some on horseback, ranged for miles driving vicuña toward the makeshift corral. Hunters then killed them and distributed their meat and wool. Over the next century, the ritual declined as the animals disappeared. New technologies enabled animals to be shorn without slaughter, offering a new way for vicuña to pay for their own conservation. A modern version of the Inca chaccu was reintroduced in Peru in 1993, using nylon nets, electric shears, and reconstituted community rituals. ${ }^{119}$

Fujimori's role as rector of the National Agrarian University La Molina and his political status as a newcomer contributed to his populist appeal and his victory over Vargas Llosa in the 1990 presidential election. He was elected on the promise not to carry out extreme austerity measures in order to stabilize the faltering economy. But he implemented them anyway. Fujimori oversaw neoliberal restructuring, which included a reduction of the state's role in rural development, especially credit and subsidies for agriculture. He also sought a private market for land holdings where titles could be freely bought and sold without upper limits on size of property. In spite of this, Fujimori was popular because he oversaw the defeat of the Shining Path and brought an end to runaway inflation. He sought and gained the support of rural communities by personally visiting them in his helicopter, dressing in the local style, and doling out small construction projects. ${ }^{120}$ Fujimori's gift to Lucanas was a renewed version of rural development on full display: the president reopened the reserve, accepted the triumph of vicuña survival, and quickly established a market for wool derived from the animals' ritual shearing. $<$ FIG. 8 NEAR HERE $>$

Although Fujimori's government had little to do with the species' recovery, the new chaccu showcased changes in the relationship between conservation and the state. At this point, vicuña stewardship devolved into a confederation of interested parties rather than a centralized bureaucratic project. Lawyers replaced scientists, and committees replaced research teams. Starting in 1992, regional vicuña management committees were established throughout the country, since vicuña now lived in areas beyond Pampa Galeras. Together they formed the National Council of South American Camelids (CONACS), which had representatives from the Ministry of Agriculture and served in an advisory

\footnotetext{
${ }^{117}$ Also spelled chaku or shaku. Arturo Flores Martinez and Efraín Malpartida Inquye, "Estudio de la selectividad y consumo de la vicuña en Pampa Galeras," Anales Científicos UNALM XXIV (1981-1985), 55-60; Catherine Teresa Sahley, Jorge Torres Vargas, and Jesús Sánchez Valdivia, "Biological Sustainability of Live Shearing of Vicuña in Peru," Conservation Biology 21, no. 1 (2007): 98-105.

118 J. J. von Tschudi, Travels in Peru during the Years 1838-1842, on the Coast, in the Sierra, across the Cordilleras and the Andes, into the Primeval Forests, trans. Thomasina Ross (New York, 1847), 220.

${ }^{119}$ In Chile, some communities now use motorcycles to gather the animals. Lichtenstein, "Vicuña Conservation and Poverty Alleviation?"; Sahley, Torres, and Sánchez, "Biological Sustainability of Live Shearing of Vicuña in Peru"; "Orgullo del mundo, privilegio del Perú," official pamphlet of Reserva Nacional Pampa Galeras Bárbara D'Achille, Ministerio del Ambiente, Servicio Nacional de Áreas Naturales Protegidas, 1999, author's collection. Nadine Heredia, the wife of President Ollanta Humala, attended the chaccu in 2012.

${ }^{120}$ Mayer, Ugly Stories of the Peruvian Agrarian Reform, 32. Drinot describes features of Fujimori's "politics of (infrastructural) spectacle" in "The Meaning of Alan García."
} 
This is an author-produced, peer-reviewed version of this article. The final, definitive version of this document can be found online at The American Historical Review, published by Oxford University Press. Copyright restrictions may apply. doi: 10.1093/ahr/rhz939

role. In 1994, the international CITES committee approved moving vicuña to CITES Appendix Two, which opened legal trade allowing the sale of more than 2,000 kilograms of live shorn fiber. In addition, a multinational consortium of largely private interests has been allowed to negotiate for fiber prices and quantities directly with member communities of CONACS. Alonso Burgos, a Peruvian wool trader associated with these firms, repeated the common mantra "A vicuña shorn is a vicuña saved." 121 Italian wool makers, especially Loro Piana, benefited greatly from the arrangement. ${ }^{122}$ In a 1995 New York Times advertisement, the firm gave notice of its plan to produce four hundred garments from legally acquired fleece. The ad reframed the animal's conservation history by claiming that "[i]llegal hunting led to the vicuña's near extinction, until Loro Piana joined the Peruvian campesinos in an effort to protect and shear the vicuña." 123 The national institutions that saved the animal were notably absent in this version just as they were in the International Wildlife cover story that portrayed vicuña as campesinos' pets. In that same year, many villagers returned to Lucanas because of the opportunities associated with new forms of vicuña conservation. One reporter noted fifty-five jobs in wool-processing. ${ }^{124}$ Private interests, rather than confidence in public goods stewarded by the state, dominated access to the limited economic advantages that derived from vicuña survival.

Starting in 1996, members of CONACS could capture and shear wild animals or implement a corral program on their community land where they could enclose hundreds of animals for long periods of time. Corrals are expensive and require that domestic livestock be removed from the land to be enclosed; shearing in the wild involves fewer immediate costs. ${ }^{125}$ Treating vicuña similarly to llama or alpaca, these alternatives share more with processes for domesticated livestock than with wildlife management, raising questions about what is being conserved. The incorporation of campesino communities into the legal trade in wool holds tremendous promise, but it is too early to determine whether the removal of strict protections on vicuña wool will once again allow poaching and the international market to endanger the animal, as anecdotal information suggests. ${ }^{126}$ Despite these new arrangements and shifting political agendas, reserves with wild animals proved the best strategy for saving the vicuña in a cause that appealed to military dictatorships and neoliberal regimes alike.

The reinvention of the chaccu and the reintroduction of wool markets extended the vicuña saga into a new century. A 2013 Wall Street Journal article showed a full-page image of a vicuña wool jacket and asked, "Why does this jacket cost \$21,000?” A small inset picturing a vicuña answered innocently, "It's because of me!" 127 The story alerted readers to a flourishing luxury market for the world's wealthiest consumers, but it did little to contextualize the reasons the animal itself avoided extinction.

How the vicuña survived seems clear: state-based, national-level conservation provided a sanctuary that allowed the animals to flourish. Peruvian conservationists - including national bureaucrats, elite benefactors, field scientists, reserve employees, and community members hosting the reserve on their territory-prevented the species from sure annihilation. Foremost in this work were the biologists and bureaucrats who designed deliberate technical operations based on repeated observations of the animal. By closely watching vicuña, scientists learned how sleeping patterns, dung piles, family groups, and soft hooves altered or restored the animals' homeland. These attributes in turn gave rise to different management strategies, although science alone never determined what policies would be enacted. Contrary to recent arguments that "conservation is failing," a suite of specific conservation measures and their enforcement undeniably succeeded in ensuring that the vicuña did not suffer the same fate as the dodo. ${ }^{128}$

\footnotetext{
${ }^{121}$ Carrasco and Zileri, "Negocio redondo."

${ }^{122}$ Andrés Bayly Letts and Enrique Pasquel Rodrigues, "Privaticemos las vicuñas: Cómo eliminar el peligro de extinción y aprovechar su potencial económico," Revista de Economía y Derecho 3, no. 9 (2006): 69-80; Lichtenstein, "Vicuña Conservation and Poverty Alleviation?”; Coggins, "Why Does a Vicuña Jacket Cost \$21,000?"

123 “You May Never Wear Vicuña but Thanks to Our Efforts, You May Meet One,” New York Times, advertisement, September 12, 1995, A7.

${ }^{124}$ Moffett, "Despues de Sendero."

${ }^{125}$ Kristi Anne Stølen, Gabriela Lichtenstein, and Nadine Renaudeau d'Arc, "Local Participation in Vicuña Management," in Iain J. Gordon, ed., The Vicuña: The Theory and Practice of Community-Based Wildlife Management (New York, 2009), 81-96, here 90. Communities pay \$22,000 for materials to construct multiple corrals to enclose $250-1,000$ animals; in practice most have fewer than 600 .

${ }^{126}$ One study found a 60 percent decrease in population between 1991 and 1994; Wheeler and Hoces, "Community Participation, Sustainable Use, and Vicuña Conservation in Peru," 286. See more recently "Matanza de vicuñas indigna a Ayacucho," May 5, 2015, https://diariocorreo.pe/peru/matanza-de-100-vicunas-indigna-a-ayacucho-585088/

${ }^{127}$ Coggins, "Why Does a Vicuña Jacket Cost $\$ 21,000 ? "$

${ }^{128}$ Peter Kareiva, Michelle Marvier, and Robert Lalasz, “Conservation in the Anthropocene: Beyond Solitude and Fragility," Breakthrough Institute (2012), https://thebreakthrough.org/journal/issue-2/conservation-in-the-anthropocene; Rodrigo Ernesto Pizarro Gariazzo, "The Global Diffusion of Conservation Policy: An Institutional Analysis” (Ph.D. thesis, Stanford University, 2012), 4.
} 
This is an author-produced, peer-reviewed version of this article. The final, definitive version of this document can be found online at The American Historical Review, published by Oxford University Press. Copyright restrictions may apply. doi: 10.1093/ahr/rhz939

Why Peruvians chose to support state-based conservation is more complex. At the national level, utilitarian arguments for the species' economic worth gained traction and motivated politicians to take the necessary steps of reserving land and restricting trade. Yet market value did not win out over charismatic sentimentalism. Claims about the animal's cultural worth, as both an ancient heritage and a modern luxury, restricted bureaucrats from completing the community development project. The Shining Path interrupted but did not entirely derail vicuña survival, and when state-based conservation reemerged, it more deeply reinforced the invented cultural association between campesinos and vicuña by reconstituting the live shearing of wild animals. Even within the context of economic austerity under neoliberal decentralization, vicuña conservation using a territorial reserve and regulated wool trade remained politically appealing for its nationalist symbolism and demonstrated effectiveness. Conservation consistently provided a mechanism - specific enough to be visible but broad enough to encompass radically different value systems - through which the state could produce new ways of relating to wild animals.

In the larger view, the vicuña saga demonstrates that species-saving state-based conservation has not been exclusively a patriotic project of liberal democracies or an undesirable effect of lingering colonial claims. Conservation remains widespread, popular, and effective in vastly different societies. ${ }^{129}$ Historians have written much about how conservationists have marginalized "local" knowledge in attempts to enact a managerial landscape. We have done less to show how conservation as a process reveals specific insights into wild animals, political continuities, development schemes, and socioeconomic endeavors. Examining where and why reserves for wild animals fail and succeed makes possible critical insight into the history, politics, and economics shaping the modern era's patterns of extinction and survival.

The author would like to acknowledge the persistence and grace of the editors and editorial staff at the $A H R$, as well as numerous anonymous readers, for their guidance in improving this article. Lisa Brady edited enough versions that she should be a co-author, and William Beezley, Michelle K. Berry, Mark Carey, Jane Carruthers, José Augusto Drummond, Claudia Leal, Nick Miller, Kirsten Pochop, Javier Puente, José Ragas, Bob Reinhardt, Patience Schell, Miles Silman and graduate seminar students at the Pontificia Universidad Católica de Chile gave critical feedback and support. J. Osciel Salazar provided essential research assistance, especially in Peru. The author appreciates the opportunity to present earlier versions at the University of British Columbia, the University of Denver, and Western Washington University, as well as the Annual Meeting of the American Historical Association in Denver. Audience suggestions enhanced it greatly. Financial support from the National Science Foundation Research Award \#1230911 in 2012 and a National Endowment for the Humanities Fellowship in 2015 made the research and writing possible.

Emily Wakild is Professor of History and Director of Environmental Studies at Boise State University in Idaho. She is the author of Revolutionary Parks: Conservation, Social Justice, and the Mexican Revolution, 1910-1940 (University of Arizona Press, 2011), which won awards from the Conference of Latin American History, the Southeastern Council on Latin American Studies, and the Forest History Society. She collaborated with Wilko Graf von Hardenberg, Matthew Kelly, and Claudia Leal to edit The Nature State: Rethinking the History of Conservation (Routledge, 2017), and with Michelle K. Berry in writing A Primer for Teaching Environmental History (Duke University Press, 2018). She is currently working on a history of science and conservation in Patagonia and Amazonia.

This article examines national efforts to protect wildlife in the twentieth century. Its focus is the vicuña, a small llamalike species native to the Andes, which nearly went extinct due to the high economic value of its wool. Instead, the Peruvian national government - despite significant regime shifts - intervened to put in place and then perpetuate a series of conservation measures, including trade restrictions and a territorial reserve, that protected thell population and allowed it to rebound. Using a combination of cultural, economic, political, and biological methods to understand the animals and people concerned about them, this article argues that conservation reoriented relationships among people and wild animals. Cultural affinities led to ethical claims about the animal's value as well as utilitarian arguments about its potential economic worth for community and economic development. Moreover, the vicuña themselves shaped both the landscapes and the conservation programs with their biological habits. Saving the vicuña proved to be a complex social process that challenged facile assumptions about past environmental actions of politically volatile, economically marginalized, and socially divided nations.

\footnotetext{
${ }^{129}$ Andrew Balmford, Jonathan M. H. Green, Michael Anderson, James Beresford, Charles Huang, Robin Naidoo, Matt Walpole, and Andrea Manica, "Walk on the Wild Side: Estimating the Global Magnitude of Visits to Protected Areas," PLOS Biology 13, no. 2 (2015), https://doi.org/10.1371/journal.pbio.1002074.
} 
This is an author-produced, peer-reviewed version of this article. The final, definitive version of this document can be found online at The American Historical Review, published by Oxford University Press. Copyright restrictions may apply. doi: 10.1093/ahr/rhz939

Keywords: nature conservation, environmental history, economic development, nationalism, political transitions

Figure 1: Vicuña family unit, Pampa Galeras, Peru. Photograph by author, 2009.

Figure 2: Cover of International Wildlife Magazine, May/June 1981. Reprinted with permission of the National Wildlife Federation.

Figure 3: Estimated vicuña population totals for Peru between 1951 and 2010 from various sources, including Censos Agropecuarios; Carl Koford, "La vicuña y la puna," unpublished report, 1951, Centro de Datos de Conservación, Universidad Nacional Agraria La Molina, Lima, Peru [CDC-UNALM]; Luis J. Cueto, Carlos F. Ponce, Eric Cardich, and Manuel A. Ríos, El manejo de la vicuña para el desarrollo rural en los Altos Andes del Perú, report, 1983, CDCUNALM; Antonio Brack Egg, "La conservación y el manejo de la vicuña como alternativa de producción en la puna," Oxapampa, Peru, 1986, 13, CDC-UNALM. Chart by author.

Figure 4: Lucanas community members supplied with instruction, housing, horses, binoculars, and rifles for reserve patrols. Frankfurt Zoological Society Archive, Projekte ZGF-Nr. 831/78.

Figure 5: Felipe Benavides Barreda nuzzling a baby vicuña. Date unknown. Reproduced with permission of Wilfredo Pérez Ruiz.

Figure 6: International Fund for Animal Welfare, pamphlet “Will the Vicuña Survive?." Reprinted with permission.

Figure 7: President Alberto Fujimori holding a baby vicuña during a shearing ceremony, 1995. Reprinted with permission of Lucien Chauvin.

Figure 8: Poster advertising a shearing festival, the National Chaccu, Pampas Galeras Reserve, 2009. Photograph by author. 